\title{
Hydrocarbon source rocks in Kazhdumi and Pabdeh formations-a quick outlook in Gachsaran oilfield, SW Iran
}

\author{
Majid Safaei-Farouji ${ }^{1}$ (D) Mohammadreza Kamali ${ }^{2} \cdot$ Mohammad Hail Hakimi $^{3,4}$
}

Received: 23 August 2021 / Accepted: 30 November 2021 / Published online: 9 December 2021

(c) The Author(s) 2021

\begin{abstract}
Geochemical study of Kazhdumi and Pabdeh Formations as potential source rocks in Gachsaran Oilfield demonstrates that the Kazhdumi Formation has a fair to good capability of hydrocarbon generation and predominately contains type II-III kerogen. On the other hand, the Pabdeh Formation has a poor to good petroleum potential and contains different kerogen types, including type II, type II-III, type III and even for one sample, type IV, indicating different depositional conditions for this formation. The geochemical log of the Kazhdumi Formation shows that there is a close correlation between different geological parameters as noticed prominently in well number 55, which suggests the more extensive the anoxic condition, the higher the petroleum potential is for Kazhdumi Formation. By contrast, a poor correlation between TOC and other Rock-Eval-derived parameters for the Pabdeh Formation at a depth of more than $2100 \mathrm{~m}$ may demonstrate the inert organic matter and mineral matrix effects at this depth interval. However, biomarkers show differences in lithology and depositional environment for the Kazhdumi Formation in well numbers 55 and 83. On the other hand, the Pabdeh Formation has a mixed lithology (carbonate-shale) deposited in a marine setting under suboxic-anoxic condition. Moreover, thermal maturity indicators suggest that Pabdeh and Kazhdumi Formations are immature and early mature, respectively.
\end{abstract}

Keywords Albian $\cdot$ Paleocene $\cdot$ Gachsaran oilfield $\cdot$ Kazhdumi formation $\cdot$ Pabdeh formation

\section{Introduction}

The middle Cretaceous to early Miocene petroleum system is the most prolific petroleum system (PS) in the Dezful Embayment and contains many Iranian oil reserves. In this embayment, Kazhdumi and Pabdeh Formations are principal organic-rich source rocks with great lateral extension. The generated hydrocarbons from these formations have been incorporated in Asmari and Bangestan reservoirs. These reservoirs are sealed through the efficient Gachsaran Formation. It is worth mentioning that the mentioned

Majid Safaei-Farouji

majid.safaei@ut.ac.ir

1 School of Geology, College of Science, University of Tehran, Tehran, Iran

2 School of Engineering, Edith Cowan University, Perth, Australia

3 Geology Department, Faculty of Applied Science, Taiz University, 6803 Taiz, Yemen

4 Department of Petroleum Engineering, Kazan Federal University, Kazan 420008, Russia petroleum system is composed of frequent fractures derived from active tectonic activities in the Zagros region (Bordenave and Hegre 2010).

The Kazhdumi (Albian) and Pabdeh (Paleocene) formations are the principal source rocks in oilfields located in the south of Iran, including the Dezful Embayment which holds about 8 percent of the world's oil reserves (Bordenave and Hegre 2005). Thus, geochemical characterization of these formations is bringing a better understanding of the depositional setting and their hydrocarbon source rock potential. So far, these formations have been studied frequently from organic geochemistry point of perspective (Bordenave and Huc 1995; Kamali et al. 2006; Alizadeh et al. 2012; Sfidari et al. 2016). Additionally, Safaei-Farouji et al. (2021) and Safaei Farouji et al. (2021) geochemically investigated the Kazhdumi and Pabdeh Formations along with oil samples in the Gachsaran Oilfield; however, detailed geochemical study of these super important formations is missing.

The Gachsaran Oilfield located in the petroliferous Dezful Embayment, with 23billion bbl of proven recoverable oil, is regarded as a supergiant oilfield (Al-Husseini 2007). 
Therefore, geochemical study of the oilfield and its corresponding source rocks is vital.

The main purpose of the present research is source rock evaluation of the two notable formations of the Kazhdumi and Pabdeh using Rock-Eval pyrolysis, organic petrography (vitrinite reflectance measurement) gas chromatography (GC) and gas chromatography-mass spectrometry analysis (GC-MS).

\section{Geological environment}

The Dezful Embayment, located at the Zagros Folded-Thrust Belt, which hosts most of the Iranian oil and gas fields, is known as the most prolific hydrocarbon basin in the Middle
East. In this depression, thick sedimentary sequences are present from the Mesozoic to Cenozoic times. As a result of the high significance of the Dezful Embayment, it has been studied in various aspects, including petroleum systems (Bordenave and Huc 1995; Bordenave 2002). The schematic map of the Dezful Embayment, Gachsaran Oilfield and stratigraphic column of the studied area, is shown in Figs. 1 and 2, respectively. The geology of the studied Kazhdumi and Pabdeh Formations is discussed below (Fig. 3).

\section{The Kazhdumi formation}

The deposition of the Kazhdumi Formation, as one of the world's most petroliferous source rocks, is an outcome of a transgression and sea-level rise in the middle Cretaceous

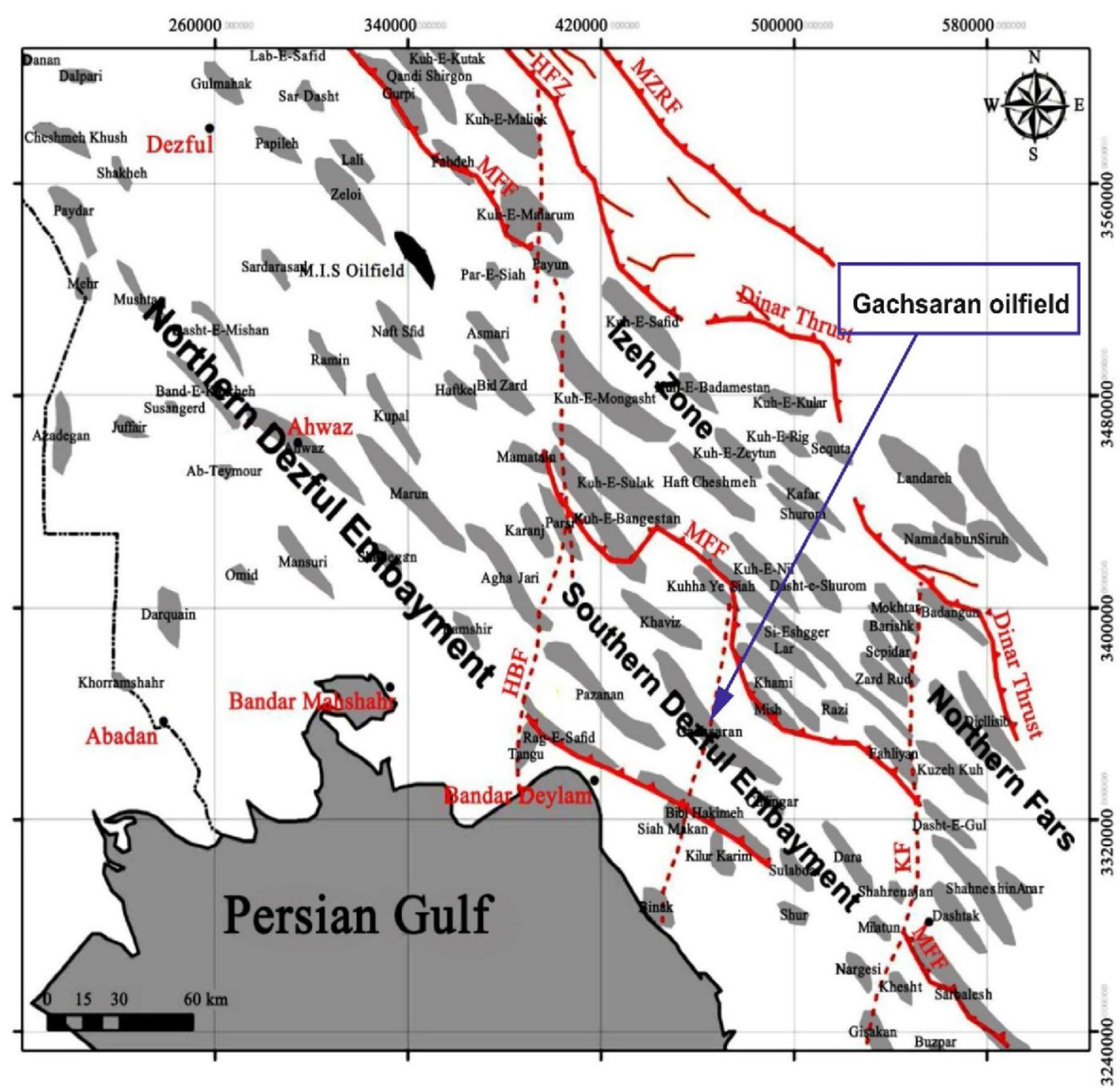

Fig. 1 The geographical location of the Dezful Embayment and Gachsaran Oilfield 


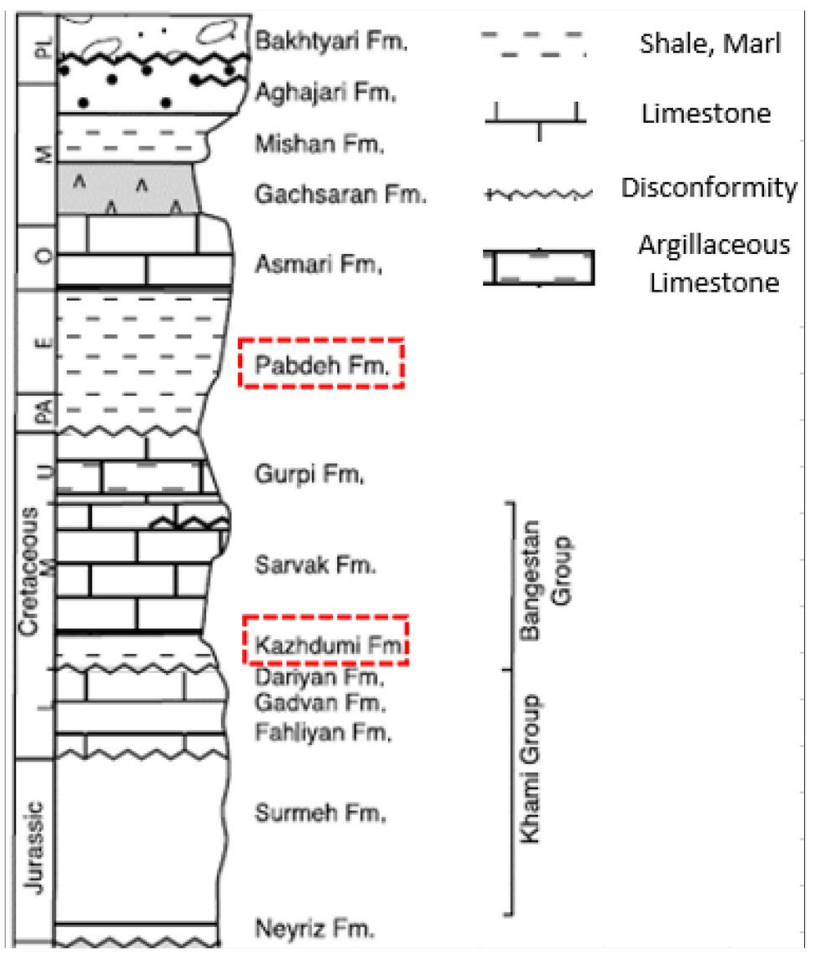

Fig. 2 Stratigraphic column of the studied area (after Sherkati and Letouzey 2004)

period (Alsharhan and Kendall 1991). During the Albian time, a widespread mild depression established in the northern section of the Dezful Embayment and Persian Gulf, and more than $300 \mathrm{~m}$ of marl rich of organic matter were deposited in the central part of this region under low-energy and anoxic conditions (Bordenave and Huc 1995). These sediments established the Kazhdumi Formation as the most significant petroleum source rock for the majority of the oil fields in the Zagros Basin (Alizadeh et al. 2012).

\section{The Pabdeh formation}

The deposition of the Argillaceous limestone and marls of the Pabdeh Formation caused by the Paleocene-Eocene transgression in deep water, anoxic depositional setting and NW-SE elongated trough parallel to the Zagros suture (Bordenave and Hegre 2005). Recent studies showed that in addition to marls and argillaceous limestones, limestone beds, deposited in a ramp setting, form a significant part of this formation (Alizadeh et al. 2012).

\section{Sampling and methodology}

A total of 120 cutting rock samples, including 93 samples from the Kazhdumi and 26 samples from Pabdeh Formations, were collected. The samples were taken from well numbers 55 and 83 in Gachsaran Oilfield.

Decontamination of samples from drilling materials, including micas and iron filings from the drill bit, was performed. After that, samples were crushed, pulverized and then homogenized. Hundred milligrams crushed whole rock sample was opted for total organic carbon (TOC) determination and Rock-Eval pyrolysis analyses. It was heated to $600{ }^{\circ} \mathrm{C}$ in a helium atmosphere, using a Rock-Eval VI apparatus manufactured by Vinci Technologies. After pyrolysis, the sample was transferred to an oxidation oven in which it was heated to $850^{\circ} \mathrm{C}$ at a rate of $25^{\circ} \mathrm{C} / \mathrm{min}$ in the company of air to oxidize all the residual
Fig. 3 The plot of $S_{1}$ against TOC to distinguish between nonindigenous and indigenous hydrocarbons embedded in the studied samples (after Hunt 1996)

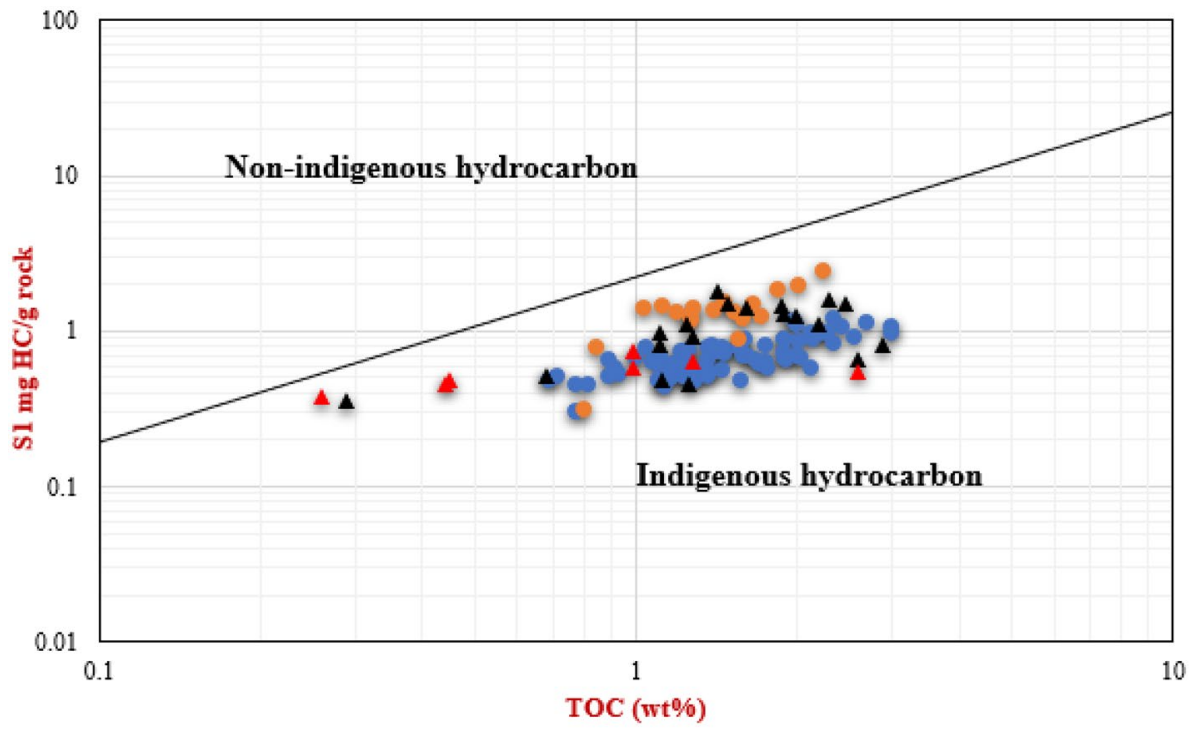

- Kazhdumi 55 Kazhdumi 83 A Pabdeh 55 A Pabdeh 83 
carbon. Data obtained from Rock-Eval analysis of samples are summarized in Table 1.

After Rock-Eval and TOC analyses, samples containing high TOC and hydrogen index values were selected to extract bitumen and perform organic petrographic investigations. Bitumen extractions were performed on the pulverized samples on approximately 30-40gr via a Soxhlet apparatus for $72 \mathrm{~h}$ using an azeotropic mixture of dichloromethane (DCM) and methanol (CH3OH) (93:7). Sulfur was eliminated through adding activated copper. The extracted bitumen was deasphaltened implemented n-hexane. Then, the extracts were separated into saturated and aromatic fractions as well as NSO (nitrogen, sulfur and oxygen) polar compounds using column (liquid) chromatography. The saturated fractions in the extracted bitumen were dissolved in hexane and analyzed using gas chromatography on gas chromatograph: Chrompack CP-9000, fitted with a glass capillary column (25-0.25 mm i.d) coated with DB-5, temperature programmed from 40 to $300{ }^{\circ} \mathrm{C}$ at a rate of $4{ }^{\circ} \mathrm{C} / \mathrm{min}$ and then held for $30 \mathrm{~min}$ at $300{ }^{\circ} \mathrm{C}$. For separation of biomarkers, Thermoquest 2000 Gas Chromatograph was used. The oven temperature program was as follows: held at $60{ }^{\circ} \mathrm{C}$ for $2 \mathrm{~min}$, heated with $3{ }^{\circ} \mathrm{C} / \mathrm{min}$ to $280{ }^{\circ} \mathrm{C}$ and kept for $40 \mathrm{~min}$. Separated molecules were transferred to mass spectrometry at $280{ }^{\circ} \mathrm{C}$. Gas chromatography-mass spectroscopy (GC-MS) analysis was utilized to investigate saturate and aromatic biomarkers. Tables 2 and 3 demonstrate data obtained from GC and GC-MS analyses, respectively.

Cutting samples crushed into 2-5 mm size particles and were treated with $\mathrm{HCl}(20 \%)$ for $8 \mathrm{~h}$ in a water bath $\left(65^{\circ} \mathrm{C}\right)$ to dissolve carbonates. Samples were treated with HF (38\%) acid to dissolve silicates for a minimum of $8 \mathrm{~h}$ or overnight in a water bath. Rinsing and washing samples were carried out for at least 3 times via a centrifuge (1500RPM). Carbonates dissolved using HCL $36 \%$ acid for minimum $8 \mathrm{~h}$ in a water bath. To perform vitrinite reflectance measurement, extracted kerogens were dried in $65{ }^{\circ} \mathrm{C}$ for some hours and then were maintained in acid.

Approximately $100 \mathrm{mg}$ of extracted and dried kerogen was transferred on a silicon mold, mixed with epoxy resin and hardener. Dried samples were grinded by abrasive (silicon carbide paper) grade 240, 320, 600 and $800 \mathrm{~mm}$, respectively. The sample was polished by alumina micropolish, 5 , $1,0.3$ and $0.05 \mathrm{~mm}$, respectively, and washed with distilled water.

The vitrinite reflectance was measured under oil immersion and in a random mode (Taylor et al. 1998). The reflected light microscope employed is computerized Letize (MPVSP), with MPV-Geor software. A sapphire glass standard with a $0.55 \%$ reflectance was used for calibration of the microscope. Table 4 shows vitrinite reflectance values for selected Kazhdumi and Pabdeh samples.

\section{Results and discussion}

\section{Oil contamination possibility}

Investigation of contamination possibility of rock samples with migrated hydrocarbons should be the first step in a source rock assessment process since contaminated samples lead to unreliable results in the following steps. According to obtained migration index $\left(\mathrm{S}_{1} / \mathrm{TOC}\right)$ values $(<1.5)$, all studied cutting samples possess indigenous hydrocarbon, representing the fact that free hydrocarbons embedded in cutting samples are generated from thermal cracking of the autochthonous organic matter (Hunt 1996; Shekarifard et al. 2019). Thus, cutting samples are considered reliable for further assessments and interpretations.

\section{Organic matter quantity and hydrocarbon generation potential}

The total organic carbon amount of the studied samples from the Pabdeh and Kazhdumi Formations is in the range of 0.26 to 2.89 wt.\% (mean $=1.35 \%$ ) and 0.62 to 2.98 wt.\% $($ mean $=1.49 \%)$, respectively (Table 1$)$.

According to (Peters 1986) classification, Kazhdumi and Pabdeh Formations based on their TOC values are regarded being "fair to very good" and "poor to very good" source rocks, respectively (Fig. 4). Therefore, it can be inferred that the Kazhdumi Formation is more productive than the Pabdeh Formation, which may represent a lower amount of inert organic matter, less mineral matrix effect as well as more anoxic condition during deposition of the Kazhdumi Formation.

However, TOC should be used cautiously on its own since some factors, including inert organic carbon (Tissot et al. 1974), thermal maturity (Daly and Edman 1987) and oil contamination (Carvajal-Ortiz and Gentzis 2015), may affect this parameter. Nevertheless, according to the plot of TOC versus $\mathrm{S}_{2}$ (Fig. 4a), both Pabdeh and Kazhdumi Formations exhibit "poor to good" petroleum potential. According to this diagram, the extensive range of the Pabdeh Formation may represent variable depositional setting conditions or successive transgression and regression of the sea level during deposition of this formation. In contrast, a stable depositional condition can be deducted for the Kazhdumi Formation. Also, from this figure, it can be concluded that the Kazhdumi Formation in well number 83 is more productive in comparison with well number 55 .

Regarding the relation between genetic potential $\left(\mathrm{S}_{1}+\mathrm{S}_{2}\right)$ and the total amount of organic carbon (TOC) (Fig. 4b), Kazhdumi and Pabdeh Formations considered as "fair to good" and "poor to good" potential source rocks, 


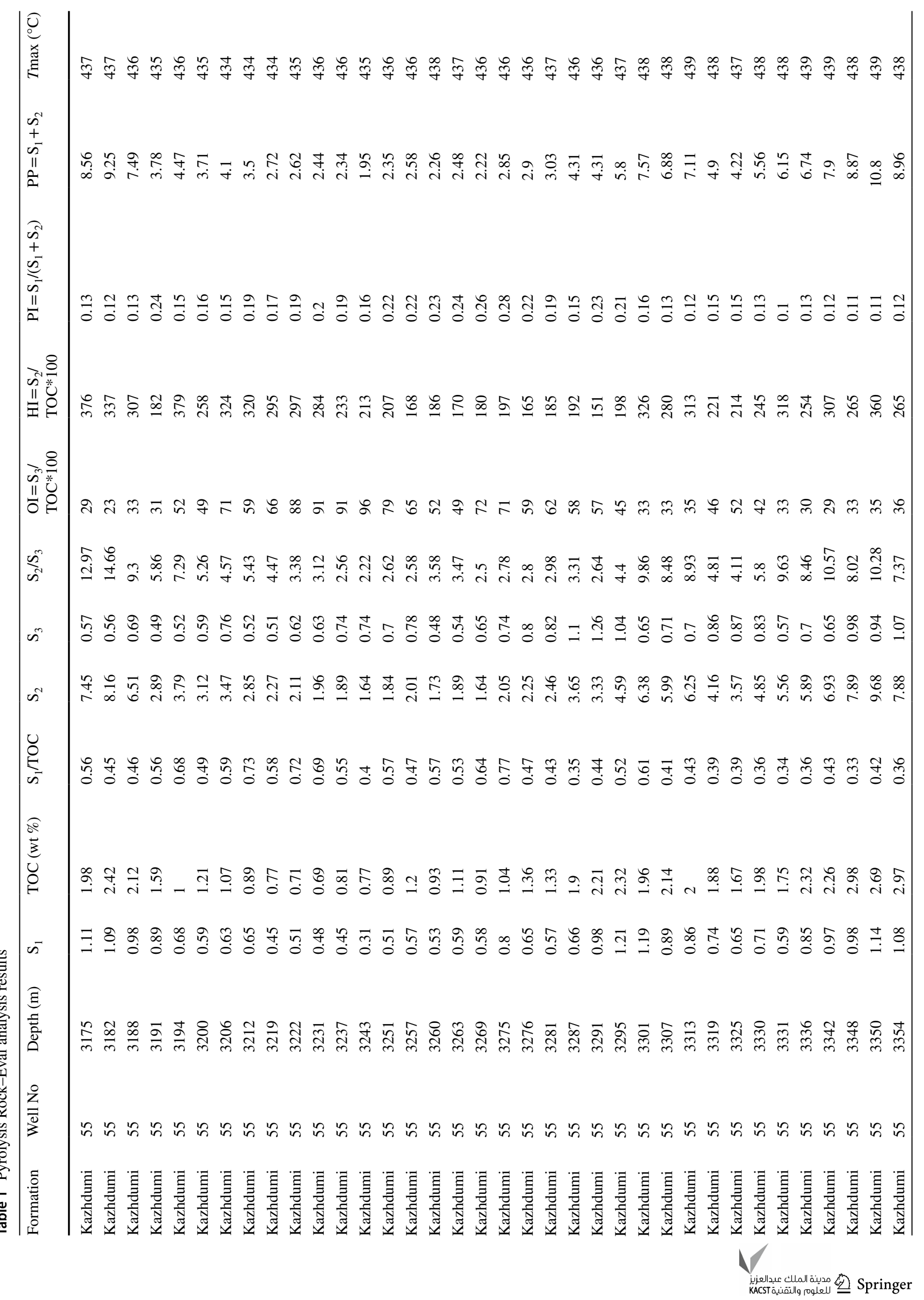




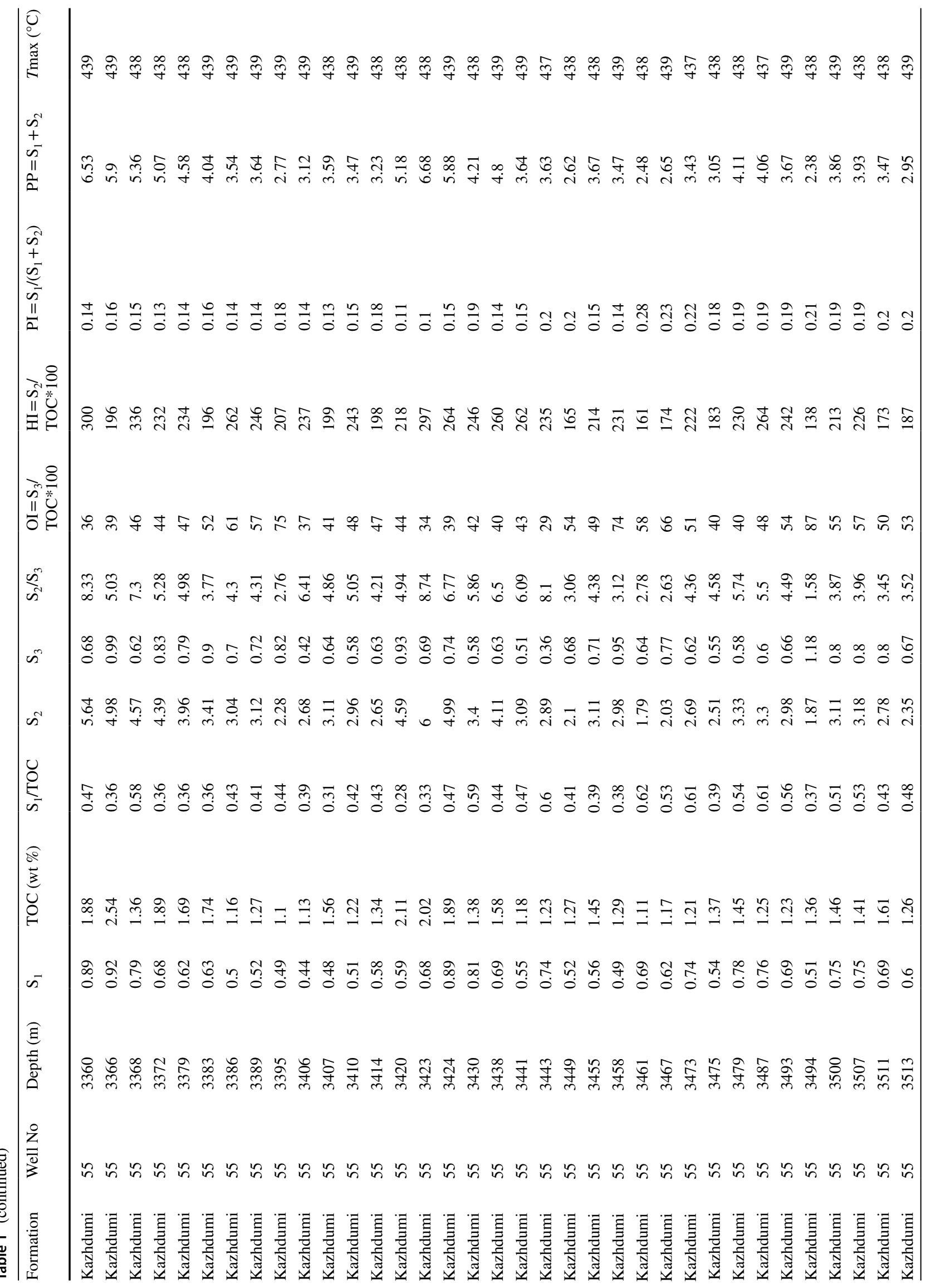




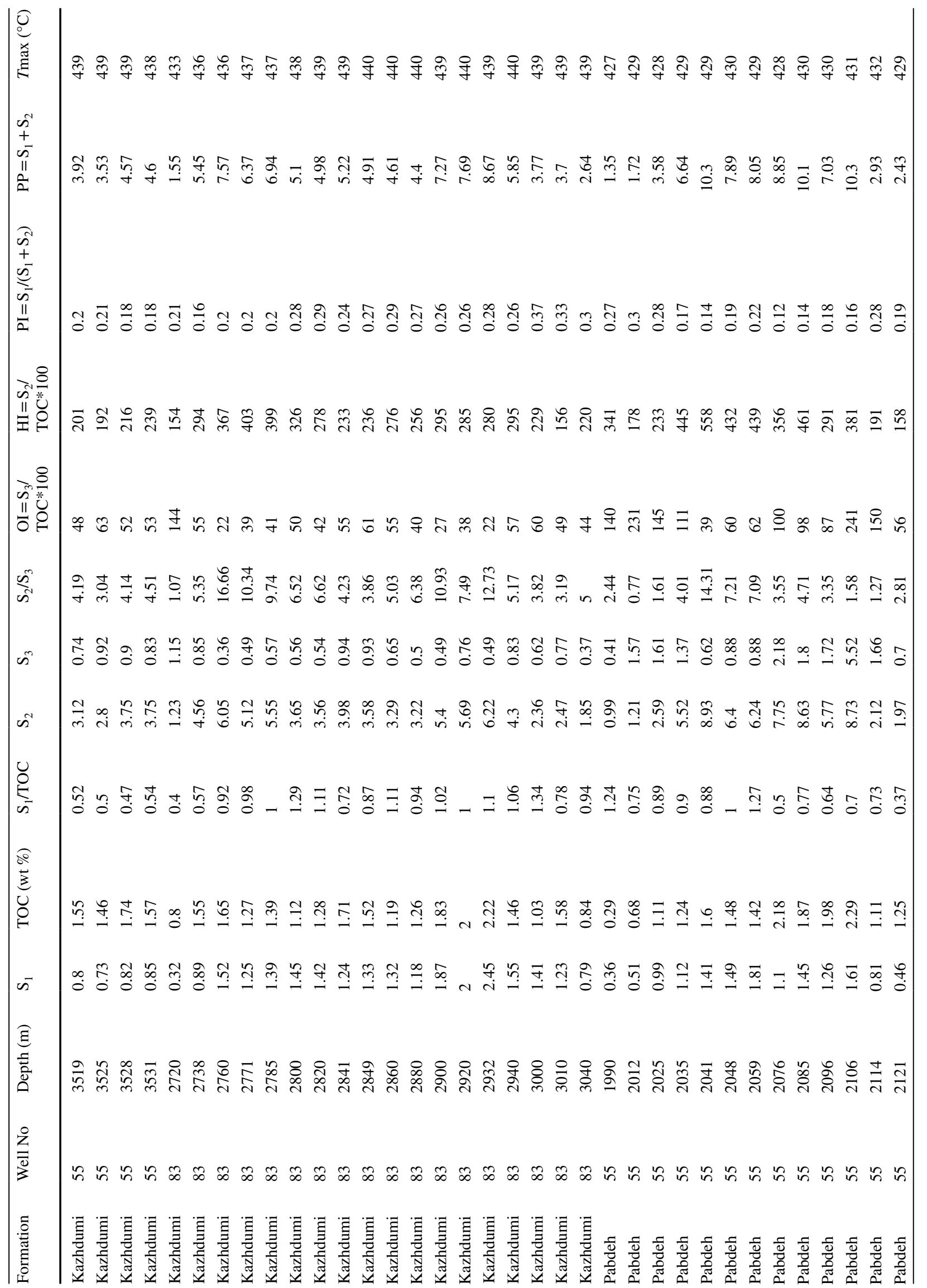




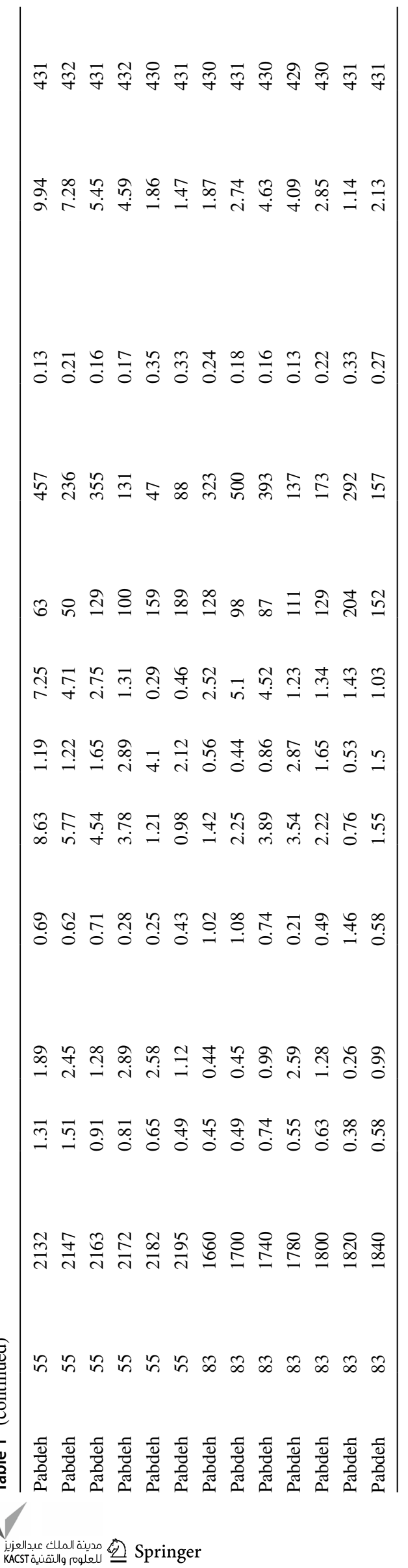

respectively. Also, from these figures, higher petroleum potential of the Pabdeh Formation in well number 55 compared to well number 83 can be inferred (Fig. 4a and b).

Petroleum potential of candidate source rocks is further investigated using the cross-plot of $S_{1}$ versus $S_{2}$ (Fig. 5a). As it can be seen on this plot, both Pabdeh and Kazhdumi Formations fall in the oil zone, representing that both formations are capable of hydrocarbon generation. However, higher content of $\mathrm{S}_{1}$ in the Kazhdumi Formation in well number 83 in comparison with well number 55 and higher values of free hydrocarbon $\left(\mathrm{S}_{1}\right)$ for the Pabdeh Formation in well number 55 in comparison with well number 83 may suggest their higher hydrocarbon generation potential. It is worth noting that the Kazhdumi Formation in well number 83 has the highest values of the free hydrocarbon $\left(\mathrm{S}_{1}\right)$; hence, it can be considered as the most productive source rock. The plot of $\mathrm{S}_{1}$ against TOC corroborates the previous deduction and indicates the higher hydrocarbon saturation for the Kazhdumi Formation in well number 83 in comparison with well 55 and for the Pabdeh Formation in well number 55 compared to well number 83 (Fig. 5b).

\section{Organic matter type and quality}

Type of organic matter is a significant characteristic which affects the quantity and quality of generated hydrocarbons (Tissot and Welte 1984). Hence, to identify oil-prone and gas-prone source rocks (Tissot and Welte 1984; Alizadeh et al. 2012), determination of the kerogen types in candidate source rocks as a vital step in source rock evaluation is essential (Hosseiny et al. 2016). As can be seen on the cross-plot of $T_{\max }$ versus hydrogen index (HI) (Fig. 6a), the Pabdeh Formation has a variety of kerogen types, including type II, type II-III, type III-II and type III kerogen and is capable of oil and gas generation. According to this diagram, the Kazhdumi Formation predominantly has kerogen mixtures (type II-III and type III-II) as well as type III kerogen; consequently, it is capable of generating both oil and gas. Among these two possible source rocks, the Pabdeh Formation has the highest content of hydrogen index. This may be derived from the lower maturity of the Pabdeh Formation, since with increasing the thermal maturity hence generating and migration of hydrocarbon, the Rock-Eval $\mathrm{S}_{2}$ subsequently hydrogen index $\left(\mathrm{S}_{2} / \mathrm{TOC} \times 100\right)$ parameters will decrease (Dembicki 2016).

Moreover, the plot of $\mathrm{S}_{2} / \mathrm{S}_{3}$ against total organic carbon (TOC) suggests that both the Kazhdumi and Pabdeh formations are oil- and gas-prone source rocks. However, the Pabdeh Formation is predominately gas-prone (Fig. 6b). Also, it is worth noting that the Kazhdumi Formation shows lower values of oxygen index than the Pabdeh Formation, suggesting more anoxic depositional setting hence the lower oxidation and better preservation of the organic matter during 
Table 2 GC analysis results of Kazhdumi and Pabdeh Formations

\begin{tabular}{llllllll}
\hline Formation & Well NO & Depth $(\mathrm{m})$ & $\mathrm{CPI}$ & $\mathrm{Pr} / \mathrm{Pr}+\mathrm{Ph}$ & $\mathrm{Pr} / \mathrm{Ph}$ & $\mathrm{Pr} / \mathrm{nC} 17$ & $\mathrm{Ph} / \mathrm{nC} 18$ \\
\hline Pabdeh & 55 & 2042 & 1.53 & 0.53 & 1.12 & 0.68 & 1.03 \\
Kazhdumi & 55 & 3441 & 0.99 & 0.57 & 1.32 & 0.73 & 0.86 \\
Pabdeh & 83 & 1740 & 1.35 & 0.53 & 1.26 & 0.78 & 1.03 \\
Kazhdumi & 83 & 3040 & 1.02 & 0.43 & 0.74 & 0.54 & 0.83 \\
\hline
\end{tabular}

$C P I=$ carbon preference index; $P r=$ pristane $P h=$ phytane and after deposition of the Kazhdumi Formation (Fig. 7) (Shekarifard et al. 2019). However, it should not be ignored that oxygen index $(\mathrm{OI})$ values can be affected by the type of the precursors and the state of the maturation.

Geochemical log of the Kazhdumi Formation (Fig. 8) shows that there is a close correlation between different parameters, the relationship between petroleum potential and redox variation, especially in well number 55 (Fig. 8a). According to this log, with increasing the anoxic condition, the petroleum potential is raised for the Kazhdumi Formation. Also, as it can be seen on this log, the Kazhdumi Formation in well number 55 (Fig. 8a) at a depth of about $3350 \mathrm{~m}$ and in well number 83 (Fig. 8b) at a depth of roughly $2930 \mathrm{~m}$ has the highest petroleum potential.

Moreover, according to the geochemical log of the Pabdeh Formation (Fig. 9), this formation in well number 55 (Fig. 9a) at a depth interval of approximately 2045 to $2100 \mathrm{~m}$ and in well number 83 (Fig. 9b) at a depth interval of 1700 to $1780 \mathrm{~m}$ possesses the highest petroleum potential.

Also, as it can be inferred from the geochemical log of the Pabdeh Formation in well number 55 (Fig. 9a), at a depth of more than $2100 \mathrm{~m}$, there is a poor correlation between TOC and other parameters, which can be attributed to the existence of inert organic matter and mineral matrix effects at this depth interval. Thus, it can be inferred from the geochemical logs that the Kazhdumi Formation than the Pabdeh Formation may be less affected by inert organic matter or mineral matrix effect.

Ternary diagram of aromatic, saturate and polar fractions (Tissot and Welte 1984) reflects both paraffinic and naphthenic compositions for the Kazhdumi Formation, while suggests a naphthenic composition for the Pabdeh Formation (Fig. 10a). Moreover, higher values of the saturate fraction for the Kazhdumi Formation compared to the Pabdeh Formation may show its higher thermal maturity (Fig. 10b).

\section{Paleo-depositional setting and lithology of the candidate source rocks}

Biological markers can be applied to reconstruct the depositional setting of formations (Sachsenhofer et al. 2010). For instance, some isoprenoids such as pristane and phytane are sensitive to redox condition. Also, some kinds of steranes and hopanes are indicative of the lithology and depositional setting of source rocks.

\section{Pristane to Phytane ratio}

Redox condition is a characteristic feature of any depositional environment that affects the accumulation and formation of organic matter (Neumeister et al. 2016). The Pristane to Phytane ratio is a useful parameter for investigation of paleo-redox conditions of source rocks ( $\mathrm{Li}$ et al. 2016). Generally, $\mathrm{Pr} / \mathrm{Ph}$ ratios greater than 3, between 1 and 3, and lower than one are indicative of oxic, suboxic and anoxic depositional environments, respectively (Philp 1985; Collister et al. 2004). It should be noted that the thermal maturity (Tissot and Welte 1984) and different acyclic isoprenoids (i.e., bacteria origin) precursors affect the $\mathrm{Pr} / \mathrm{Ph}$ ratio (Volkman 1986). However, regarding the thermal maturity of the Pabdeh Formation (pre-oil window) in comparison with the Kazhdumi Formation, the Pabdeh Formation has been less affected and subtly may be changed with thermal maturity (Hughes et al. 1995; Hao et al. 2012), while the impact of maturation (Tissot and Welte 1984) cannot be ruled out because of the higher thermal maturity of the Kazhdumi Formation than the Pabdeh Formation. Nonetheless, the obtained $\mathrm{Pr} / \mathrm{Ph}$ ratio for the Kazhdumi Formation in well number $83(0.74)$ represents an anoxic depositional environment during deposition of this formation, while the value of this ratio for the Kazhdumi Formation in well number 55 (1.32) suggests a suboxic condition. Also, values for the Pabdeh Formation in well number 55 (1.12) and in well number 83 (1.26) reflect a suboxic depositional condition (Fig. 11a). Additionally, the obtained $\mathrm{C}_{29} / \mathrm{C}_{27}$ steranes ratio (Fig. 11a) clarifies marine depositional environment for both the Kazhdumi and Pabdeh Formations.

\section{$C_{27} C_{28}$ and $C_{29}$ regular steranes}

Relative amounts of $\mathrm{C}_{27}, \mathrm{C}_{28}$ and $\mathrm{C}_{29}$ regular steranes can be employed for investigation of the organic matter type and paleo-depositional environment (Philp 1985; Peters and Moldowan 1993; Hosseiny et al. 2016). In general, $C_{27}, C_{28}$ and $\mathrm{C}_{29}$ sterols are generated from phytoplankton or marine algae, lake algae and land plants, respectively (Huang and Meinschein 1979; Peters et al. 2005). Ternary diagram of

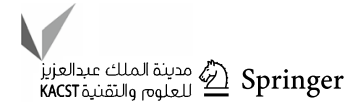




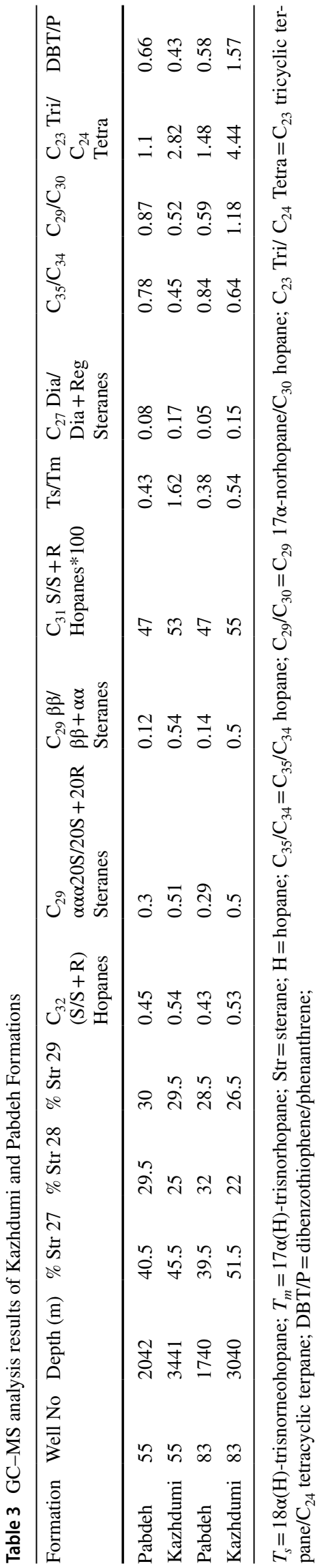

$\mathrm{C}_{27}, \mathrm{C}_{28}$ and $\mathrm{C}_{29}$ regular steranes distribution (Fig. 11b) (Huang and Meinschein 1979) for Pabdeh and Kazhdumi Formations suggests an open marine depositional setting for both of them. However, this cross-plot represents a more significant contribution of marine algae rather than terrestrial higher plants for the Kazhdumi Formation compared to the Pabdeh Formation. Moreover, a more significant contribution of marine algae can be inferred for the Kazhdumi Formation in well 83 by comparison with well 55. Also, the cross-plot of $\mathrm{C}_{29} / \mathrm{C}_{27}$ steranes ratio against $\mathrm{Pr} / \mathrm{Ph}$ ratio (Fig. 11a) typifies the Pabdeh Formation contains marine organic matter deposited under suboxic condition, while the Kazhdumi Formation has marine organic matter which in well number 55 and 83 deposited under suboxic and anoxic conditions, respectively.

\section{$\mathrm{C}_{23}$ tricyclic/ $\mathrm{C}_{24}$ tetracyclic terpanes ratio}

The nature of the depositional conditions can be further confirmed by evaluating of $\mathrm{C}_{23}$ tricyclic terpane/ $\mathrm{C}_{24}$ tetracyclic ratio values. High values of $\mathrm{C}_{23}$ tricyclic terpane/ $\mathrm{C}_{24}$ tetracyclic ratio $(>1)$ suggest marine depositional environment, while low values $(<1)$ indicate the terrigenous origin of organic matter (Hanson et al. 2000). The high values of this ratio $(>1)$ for both Kazhdumi and Pabdeh Formations (2.82 and 1.48 for the Kazhdumi and 1.1 and 1.44 for the Pabdeh Formation) denote marine depositional environment for them. These values, however, are higher for the Kazhdumi Formation (especially in well number 83) which can be due to a more significant contribution of marine algae rather than terrestrial higher plants concluded from values of regular steranes.

\section{Dibenzothiophene to phenanthrene (DBT/P) ratio}

The DBT/P ratio has been employed to distinguish between shaly and carbonate source rocks. Commonly, values higher than one depict carbonate/marl sediments, while values lower than 1 show a shaly source rock (Hughes et al. 1995). Low concentration of this ratio for the Pabdeh Formation (0.66 and 0.58$)$ is indicative of shaly lithology. However, the value of this ratio for the Kazhdumi Formation in well number $55(0.43)$ reflects shaly organic facies, while the value of this ratio for this Formation in well number 83 (1.57) represents carbonate lithology (Fig. 12a).

\section{$\mathrm{C}_{35} / \mathrm{C}_{34}$ homohopane ratio}

The $\mathrm{C}_{35} / \mathrm{C}_{34}$ homohopane ratio is a useful biomarker ratio that can be implemented for investigation of the paleo-redox condition or paleo-depositional facies characteristics. Values higher than 0.8 are indicative of the prevalence of anoxic bottom water during deposition of source rocks (Peters et al. 
Table 4 Vitrinite reflectance measurements for Kazhdumi and Pabdeh Formations

\begin{tabular}{lllllll}
\hline Formation & Well No & Depth $(\mathrm{m})$ & Sample type & Min, Ro\% & Max, Ro\% & Mean Ro\% \\
\hline Kazhdumi & 55 & 3182 & Cutting & 0.44 & 0.99 & 0.59 \\
Kazhdumi & 55 & 3360 & Cutting & 0.45 & 1.12 & 0.65 \\
Kazhdumi & 55 & 3423 & Cutting & 0.45 & 1.12 & 0.68 \\
Kazhdumi & 55 & 3531 & Cutting & 0.47 & 1.25 & 0.71 \\
Kazhdumi & 83 & 2720 & Cutting & 0.42 & 0.97 & 0.63 \\
Kazhdumi & 83 & 3040 & Cutting & 0.58 & 1.2 & 0.68 \\
Pabdeh & 55 & 2000 & Cutting & 0.25 & 0.44 & 0.38 \\
Pabdeh & 55 & 1740 & Cutting & 0.28 & 0.49 & 0.32 \\
\hline
\end{tabular}

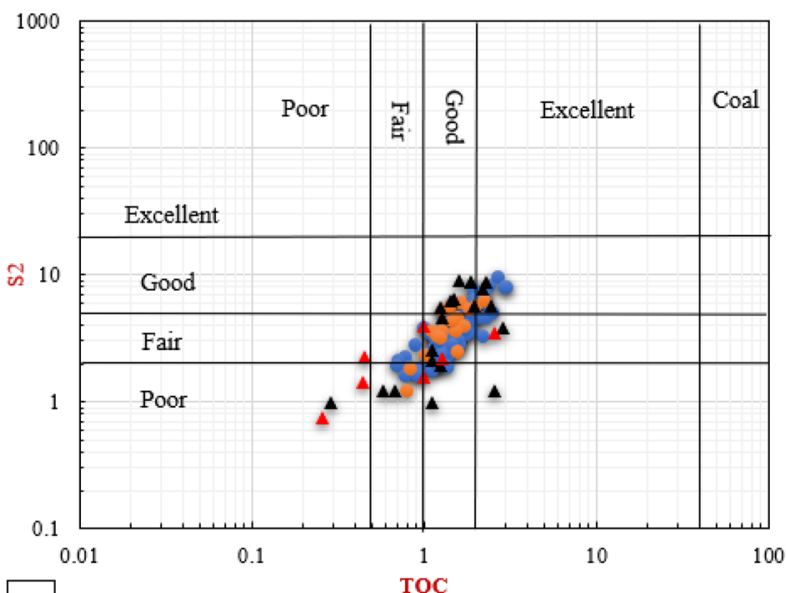

a

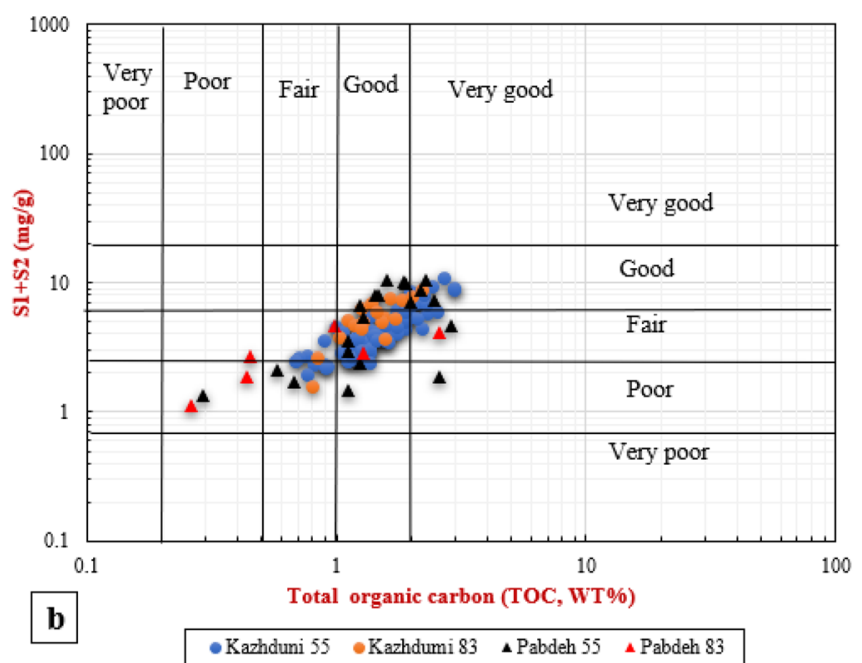

$\bullet$ Kazhduni 55 Kazhdumi $83 \quad$ A Pabdeh 55 A Pabdeh 83

Fig. 4 a Cross-plot of TOC against $S_{2}$ ( modified from Peters and Cassa 1994) and b TOC versus genetic potential $\left(S_{1}+S_{2}\right)($ after Waples 1985$)$ illustrating the petroleum potential of the formations
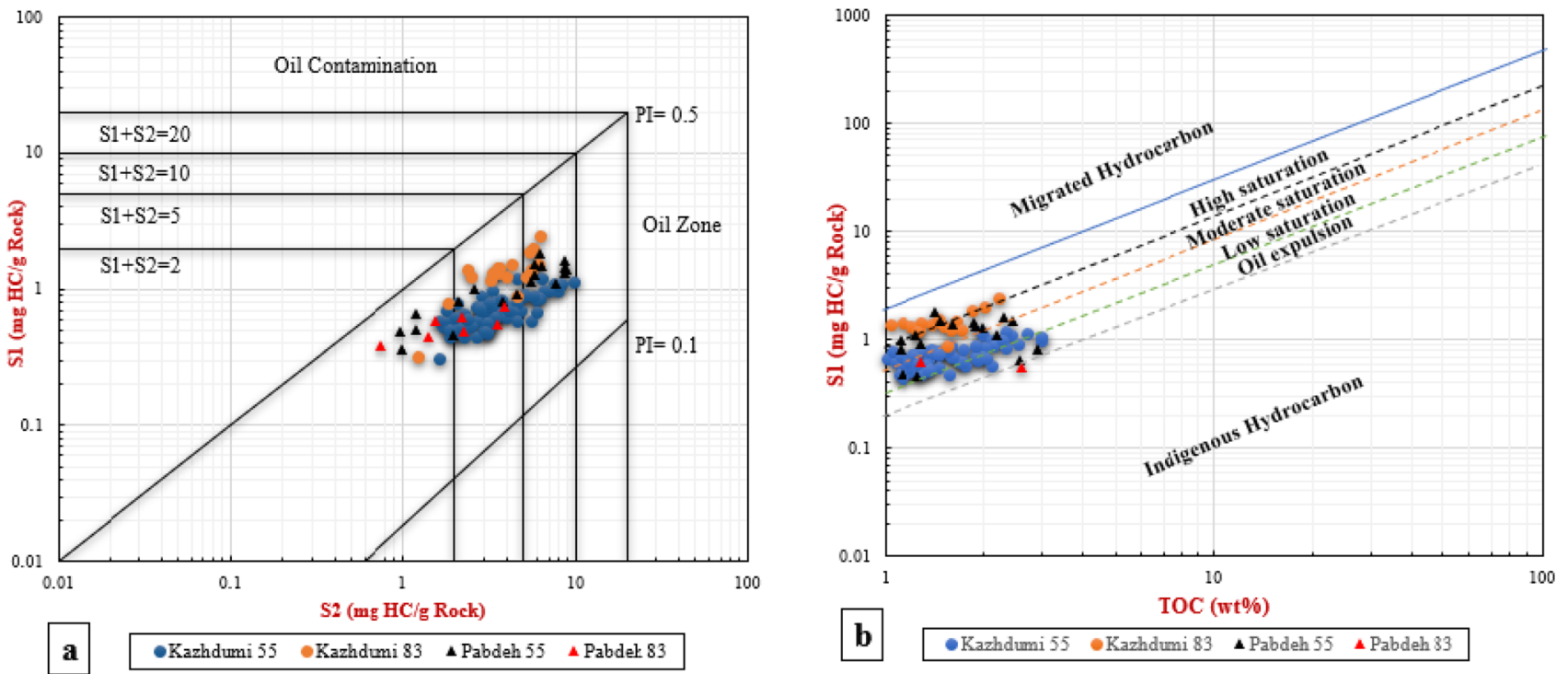

Fig. 5 a Cross-plot of $S_{1}$ against $S_{2}$ representing the petroleum potential of possible source rocks and $\mathbf{b}$ cross-plot of total organic carbon (TOC) versus free hydrocarbon values $\left(S_{1}\right)$ showing hydrocarbon saturation of possible source rocks (modified after Sar1 et al. 2012) 


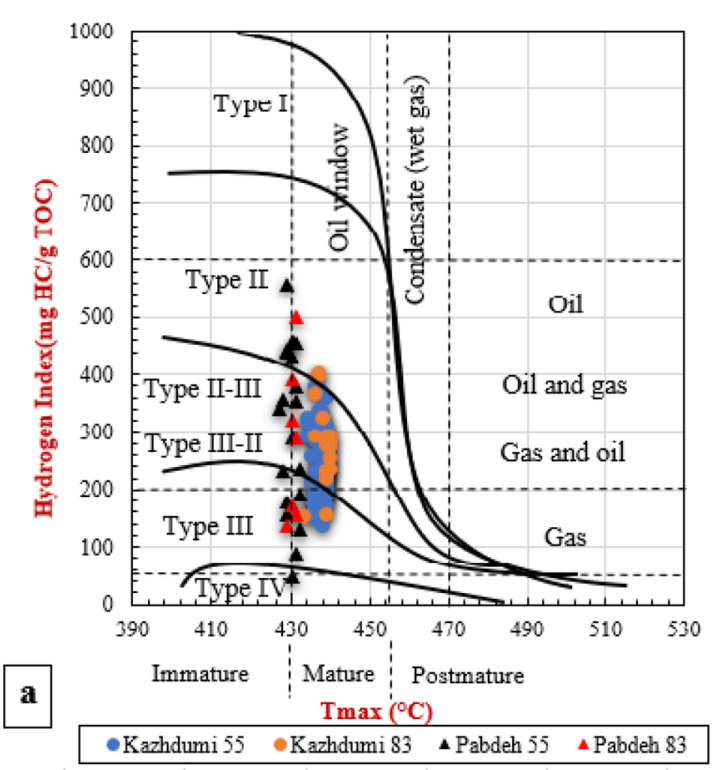

Fig. 6 a Cross-plot of hydrogen index (HI) against pyrolysis $T_{\max }$ for the analyzed samples, illustrating kerogen and hydrocarbon generation type (modified after Yandoka et al. 2016) and b cross-plot of

2005). The $\mathrm{C}_{35} / \mathrm{C}_{34}$ homohopane ratio for the Pabdeh Formation (0.78 in well number 55 and 0.84 in well number 83 ) suggests deposition of this Formation under anoxic-suboxic condition (Fig. 12b). In contrast, the obtained values for the

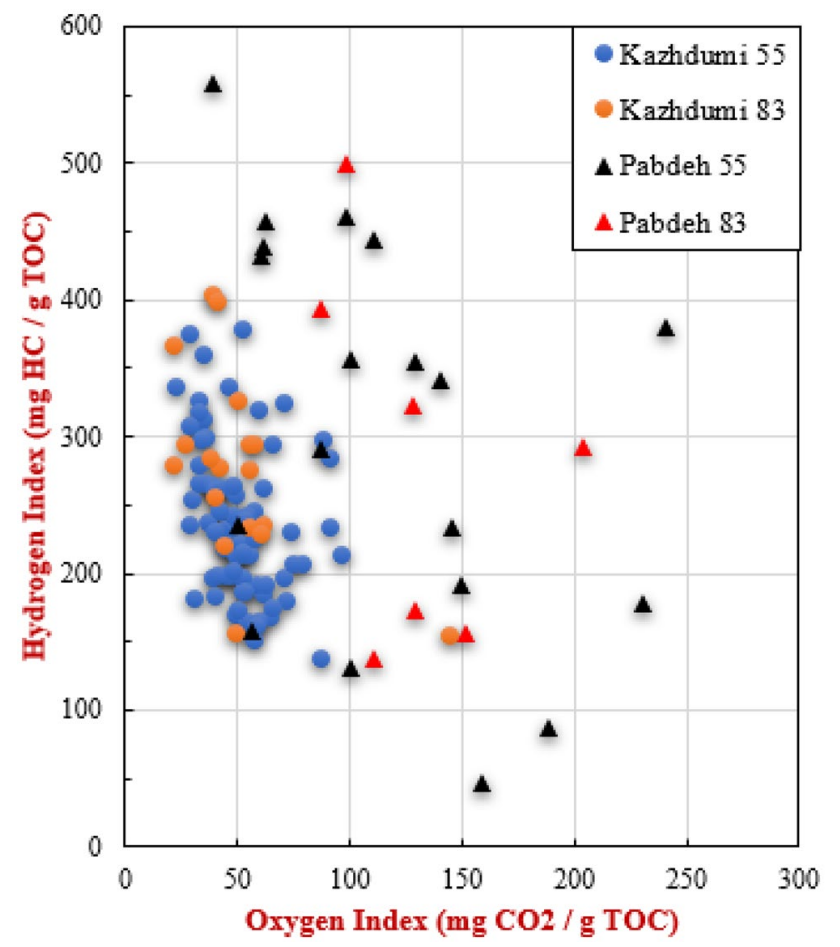

Fig. 7 Plot of OI versus HI, illustrating the better preservation of organic matter for the Kazhdumi Formation

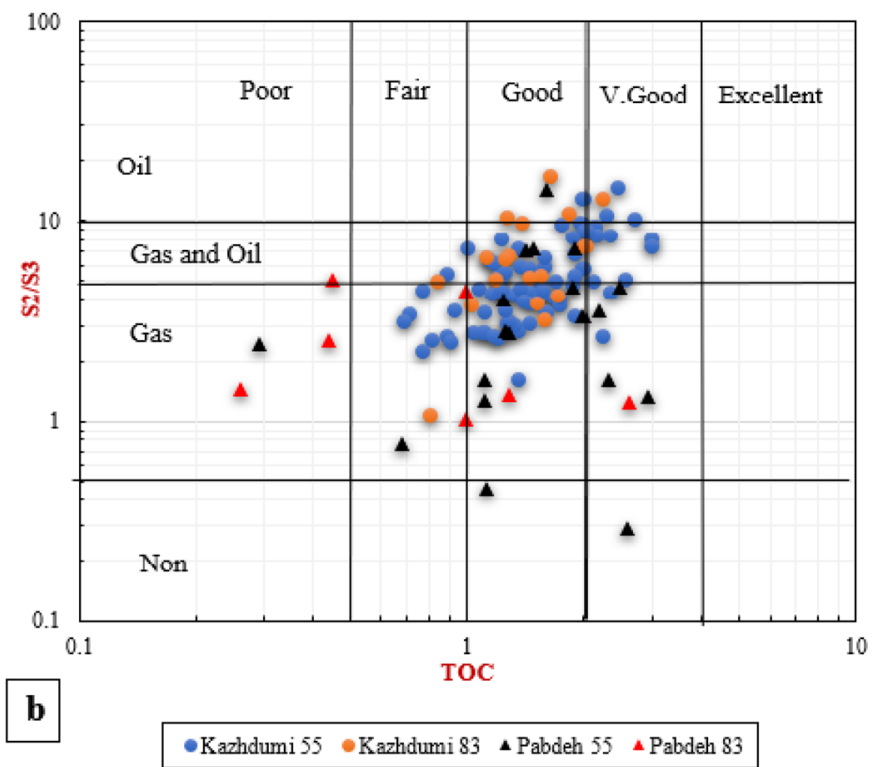

TOC versus $\mathrm{S}_{2} / \mathrm{S}_{3}$ in order to determination of the hydrocarbon generation types (after Maravelis et al. 2017)

Kazhdumi Formation (0.45 in well number 55 and 0.64 in well number 83) denote suboxic condition during deposition of this Formation (Fig. 12b). Therefore, the paleo-redox condition inferred from the $\mathrm{C}_{35} / \mathrm{C}_{34}$ homohopane ratio is not consistent with that of deducted from the $\mathrm{Pr} / \mathrm{Ph}$ ratio. This difference may be due to the impact of other factors on the $\mathrm{Pr} / \mathrm{Ph}$ ratio discussed earlier. Therefore, it can be inferred that the $\mathrm{C}_{35} / \mathrm{C}_{34}$ homohopane ratio is more reliable than the $\mathrm{Pr} / \mathrm{Ph}$ ratio.

\section{$\mathrm{C}_{29} / \mathrm{C}_{30}$ hopanes ratio}

This ratio is high (relatively 0.7 or higher) in carbonate and evaporite source rocks, whereas low values (0.4-0.75) speak for terrigenous or shaly source rocks (Zumberge 1984; Peters and Moldowan 1993). This ratio for the Kazhdumi Formation in well number 55 (0.52) and well number 83 (1.18) typifies shaly and carbonate organofacies, respectively. Likewise, this ratio for the Pabdeh Formation represents different shaly and carbonate lithology (Fig. 12b).

\section{Ts/Tm ratio}

This ratio depends on both lithology and thermal maturity (Moldowan et al. 1986). Carbonate formations demonstrate uncommonly low values of the $T_{s} / T_{m}$ ratio. Also, this ratio rises as thermal maturity advances (Waples 1991; Peters and Moldowan 1993). Moreover, the $T_{s} / T_{m}$ ratio values lower than 0.6 (Peters et al. 2005) or 0.5 (Mello et al. 1988) typify clay-poor anoxic marine carbonate depositional 

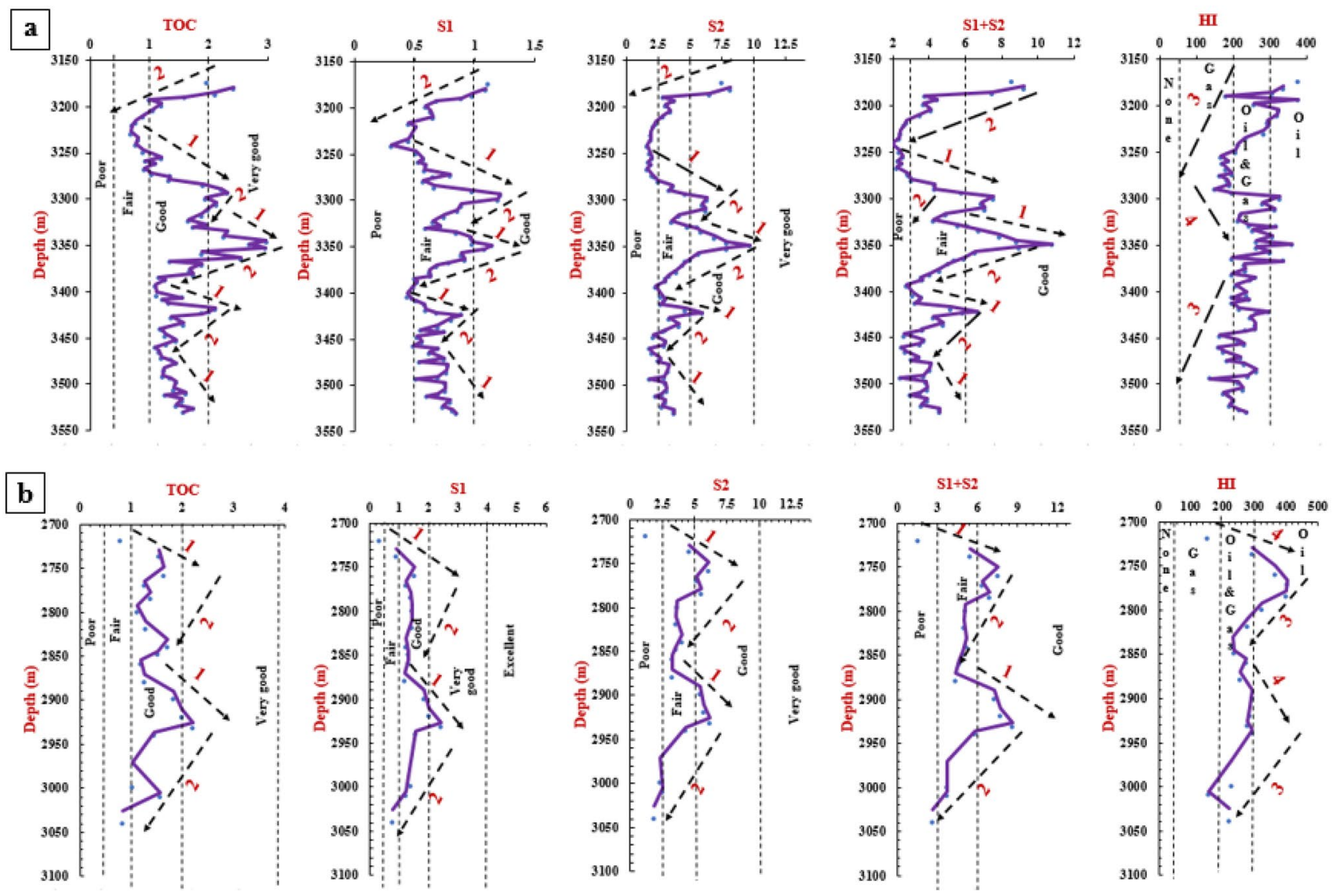

Fig. 8 Geochemical log of the Kazhdumi Formation in well number 55 (a) and 83 (b). 1: Increasing petroleum potential, 2: decreasing petroleum potential, 3: decreasing anoxic condition, 4: increasing anoxic condition, 5: increasing oxic condition and 6: decreasing oxic condition

environments. Considering the same level of the maturity for the Kazhdumi Formation in both studied wells, approximately considerable different values of the $T_{s} / T_{m}$ ratio for the two samples belong to the Kazhdumi Formation (0.54 and 1.62) and mark different organic facies, including shaly in well 55 and carbonate in well 83 for this Formation corroborating previous outcomes deducted from other lithology-related biomarker ratios. Also, the low values of the $T_{s} / T_{m}$ ratio for the Pabdeh Formation (0.43 to 0.38 ) typify a clay-poor anoxic depositional setting. However, the higher values of the ratio for the Kazhdumi Formation relative to the Pabdeh Formation can be a sign of higher maturity of the Kazhdumi Formation (Fig. 13a).

\section{$C_{27}$ diasterane to $C_{27}$ regular sterane ratio}

This ratio is both lithology and maturity sensitive. With increasing the thermal maturity and clay content, the $\mathrm{C}_{27}$ diasteranes would be increased (Dembicki 2016; Peters et al. 2005). The obtained values of this ratio for the Pabdeh Formation (0.05 and 0.08) can be related to its low thermal maturity or carbonate (clay free) facies. By contrast, the higher values of this ratio for the Kazhdumi Formation (0.15 and 0.17) suggest its higher level of thermal maturity or higher clay content compared to the Pabdeh Formation. However, it should be noted that the Kazhdumi Formation is located in the range of the carbonate source rocks (Fig. 13b).

\section{Thermal maturity}

Thermal evolution of organic matter plays a crucial role in hydrocarbon generation; thus, the assessment of organic matters thermal maturity is of high importance (Hosseiny et al. 2016). $T_{\max }$, representing the temperature (in ${ }^{\circ} \mathrm{C}$ ) at which the $\mathrm{S}_{2}$ peak is maximum (Dembicki 2016), is the first Rock-Eval parameter for evaluation of thermal maturity.

In general, typical $T_{\max }$ values for the top and bottom of the oil window are almost $435-445$ and $470{ }^{\circ} \mathrm{C}$, respectively (Espitalié, 1986). It should be noted, in order to calculate reliable $T_{\max }$ values, $\mathrm{S}_{2}$ contents must be higher than $0.2(\mathrm{mg}$ $\mathrm{HC} / \mathrm{g}$ rock) (Peters 1986). All of the studied samples in this research possess $\mathrm{S}_{2}$ values higher than 0.2 ; hence, $T_{\max }$ considered as a reliable thermal maturity-related indicator. Also, production index $\left(\mathrm{S}_{1} / \mathrm{S}_{1}+\mathrm{S}_{2}\right)$ is an alternative parameter to 

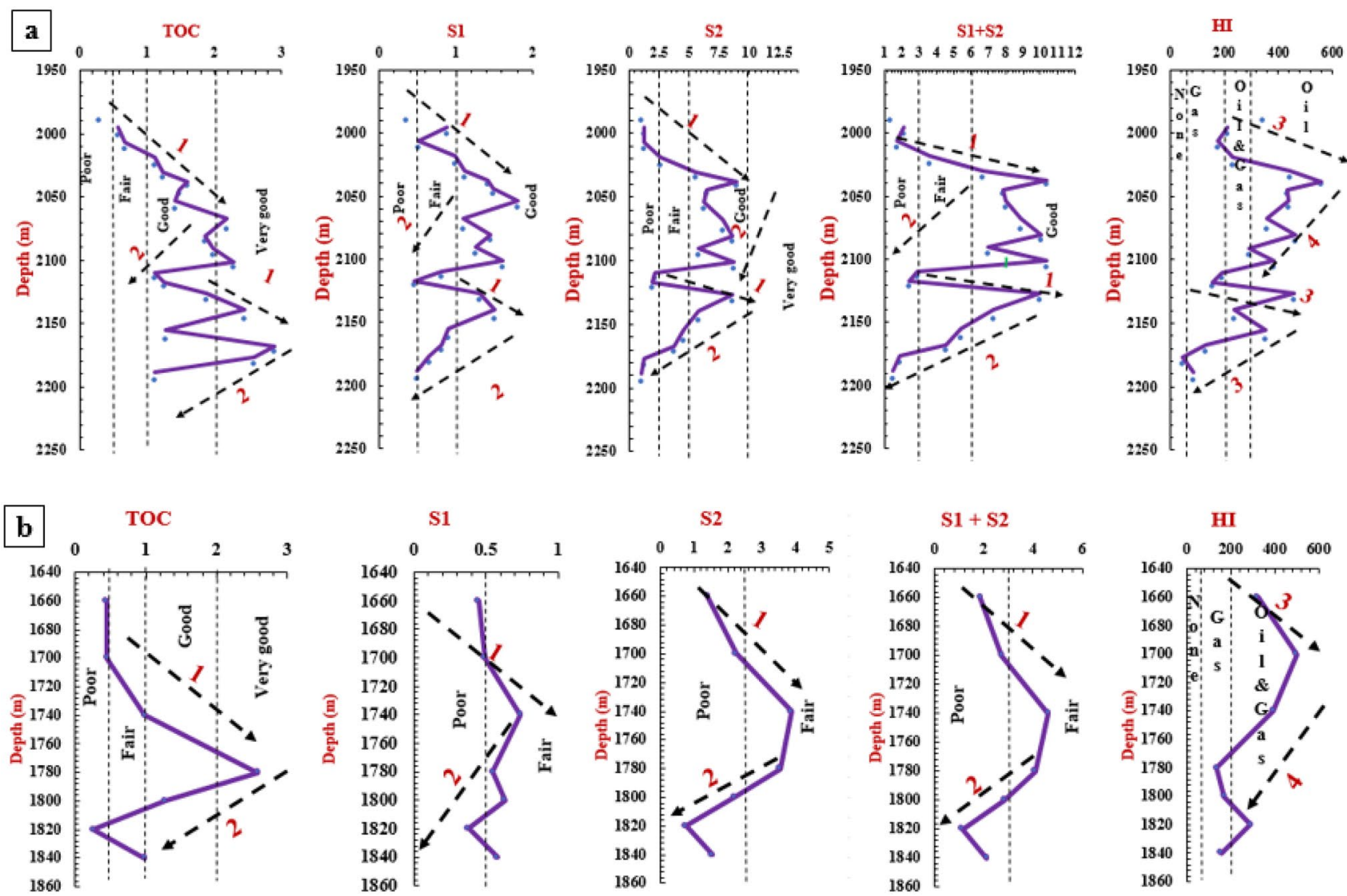

Fig. 9 Geochemical log of the Pabdeh Formation in well number 55 (a) and 83 (b). 1: Increasing petroleum potential, 2: decreasing petroleum potential, 3: decreasing anoxic condition, 4: increasing anoxic condition, 5: increasing oxic condition and 6: decreasing oxic condition

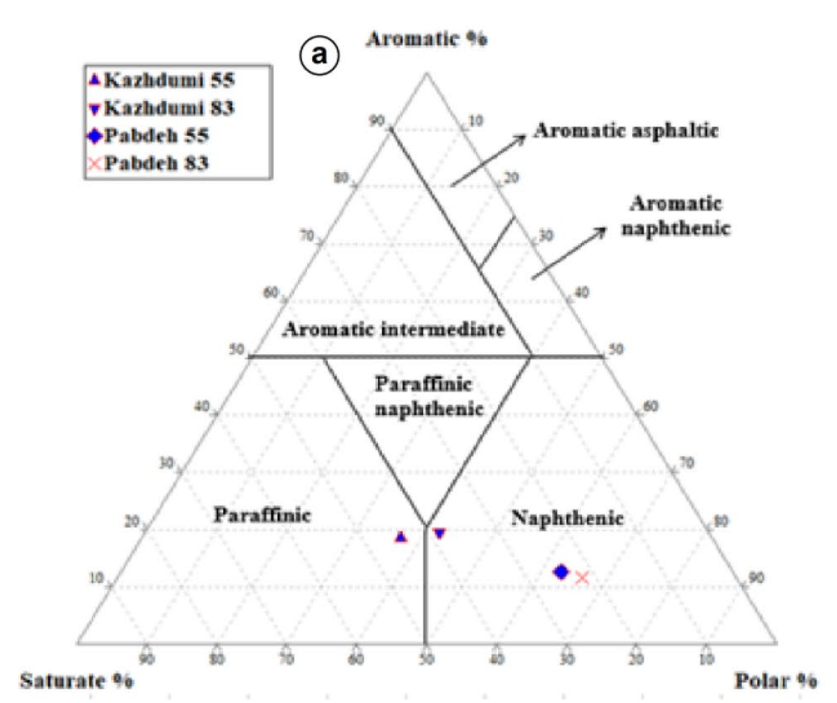

Fig. 10 Ternary diagrams of aromatic, saturate and polar fractions extracted from bitumen embedded in source rocks in order to determine a chemical composition of bitumen in the analyzed source rocks

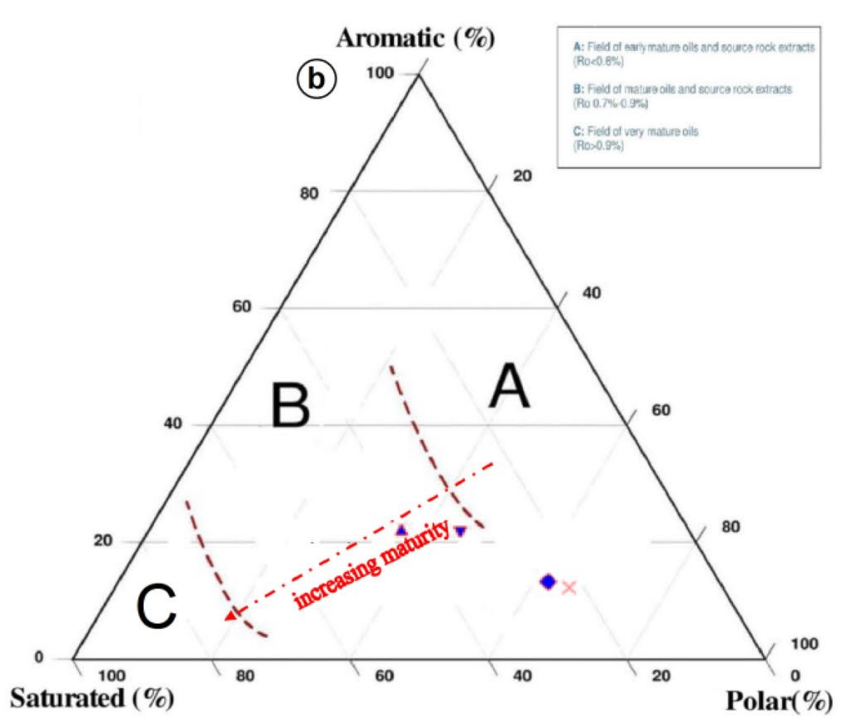

(Tissot and Welte 1984) and b maturation of the analyzed source rocks (modified after Peters et al. 2005) 

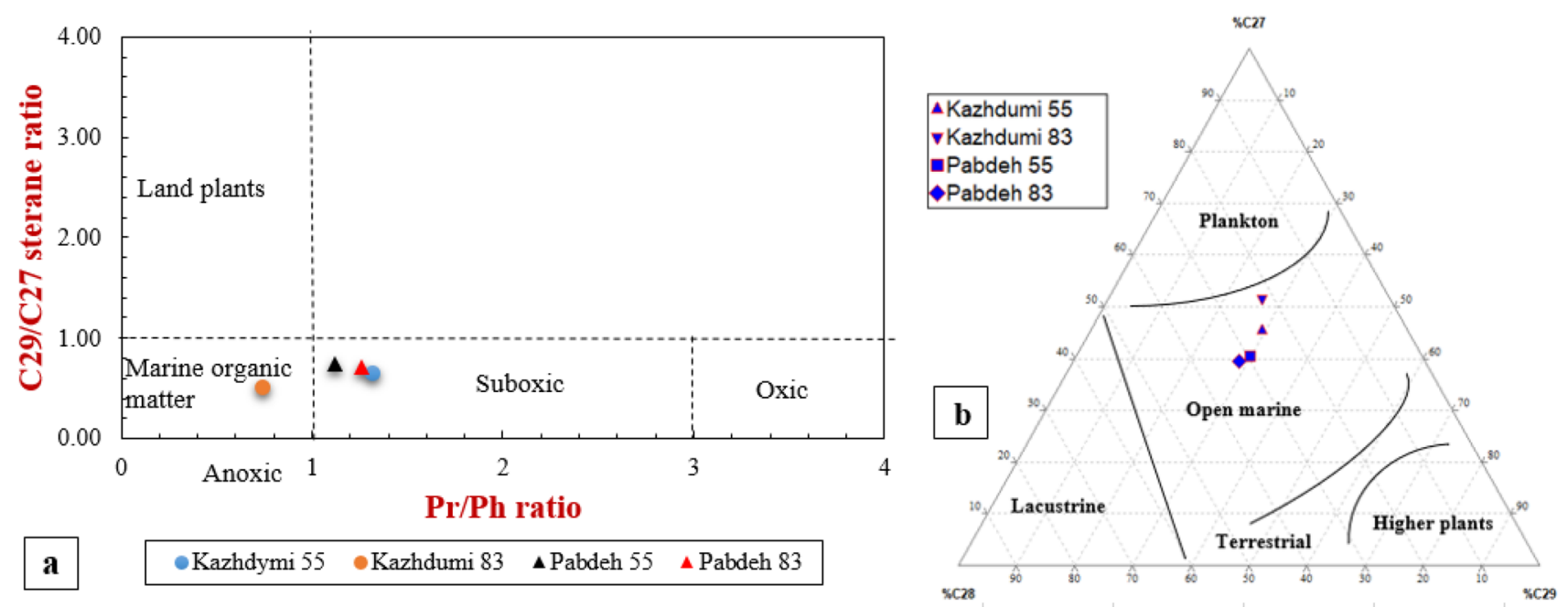

Fig. 11 a Cross-plot of $\mathrm{C}_{29} / \mathrm{C}_{27}$ steranes ratio against $\mathrm{Pr} / \mathrm{Ph}$ ratio for investigation of depositional setting (modified after Peters et al. 2005) and b ternary diagram of $\mathrm{C}_{27}, \mathrm{C}_{28}$ and $\mathrm{C}_{29}$ regular sterane concentrations (Huang and Meinschein 1979)
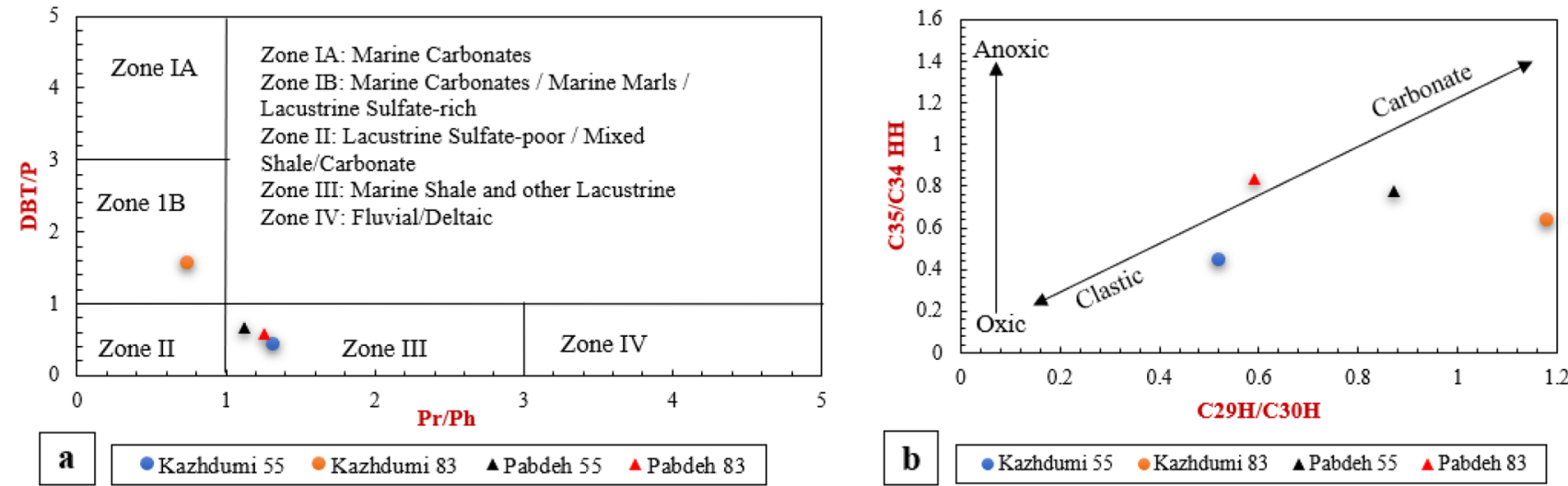

Fig. 12 a Plot of DBT/P ratio against $\mathrm{Pr} / \mathrm{Ph}$ ratio (Hughes et al. 1995) and $\mathbf{b}$ cross-plot of C29/C30 hopanes against C35/C34 homohopanes (modified after Peters et al. 2005) illustrating the depositional environment of candidate source rocks
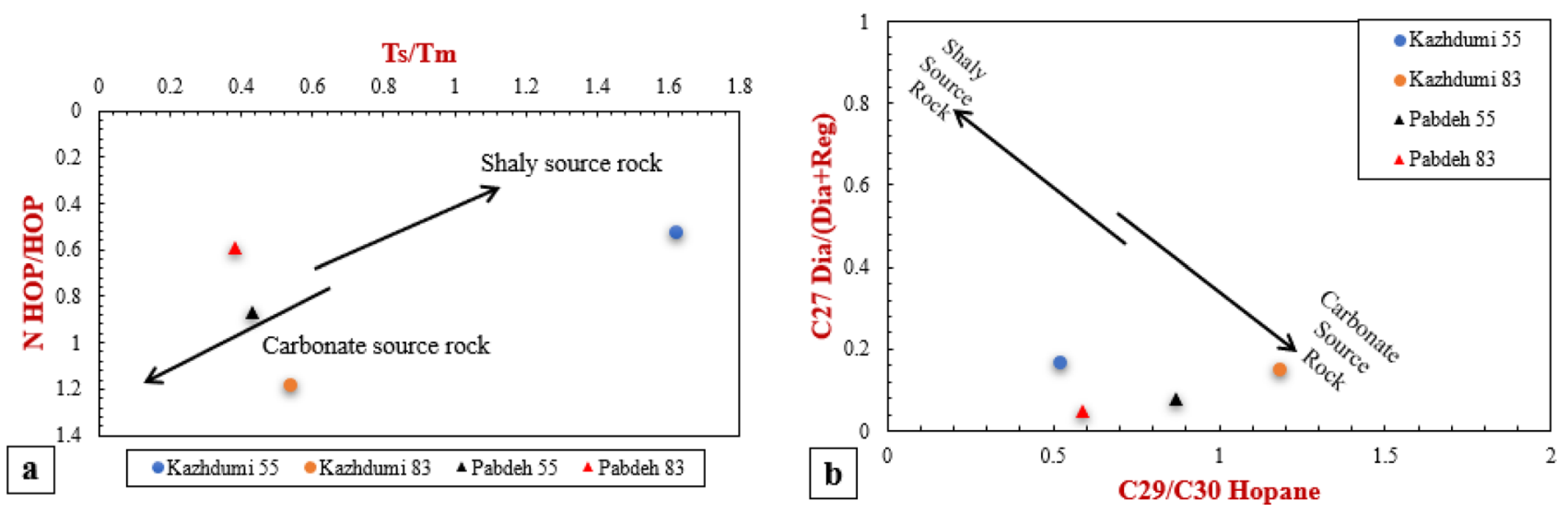

Fig. 13 a Cross-plot of $T_{s} / T m$ versus $C_{29} / C_{30}$ hopanes and $\mathbf{b}$ cross-plot of $\mathrm{C}_{29} / \mathrm{C}_{30}$ hopanes against $\mathrm{C}_{27}$ Dia/Dia + regular steranes speaking for lithology of source rocks (modified after Peters et al. 2005) 
thermal maturity assessment. Values higher than 0.1 and 0.4 indicate mature and super-mature phases, respectively (Peters and Moldowan 1993).

Based on the plot of $T_{\max }$ against PI (Fig. 14a), the Kazhdumi Formation falls in the oil generation window showing it has reached sufficient thermal maturity to generate hydrocarbon. By contrast, the Pabdeh Formation considered as an immature source rock. According to this figure and production index values, the Kazhdumi Formation in well number 83 by comparison with well number 55 has higher production index and hence regarded as a more productive Formation.

Generally, as a result of the gradual increase of the heating history and geothermal gradient for organic matter with a rise in depth, the thermal maturity of organic matter would steadily change from immature to mature stage. Accordingly, the higher thermal maturity is for the organic matter or formation buried in deeper horizon (the Kazhdumi Formation), and lower maturity is for the organic matter and formation buried in shallower horizon (the Pabdeh Formation) (Lerch et al. 2016; Peters et al. 2005).

Vitrinite reflectance (Ro\%) is the most effective, reliable and widely employed parameter to determine the thermal maturity of organic matter in formations (Dow 1977; Baban and Ahmed 2014; El Diasty 2015; Zhang and Li 2018). In general, mean vitrinite reflectance value at the top of oil window is $0.6 \%\left(T_{\max }=435{ }^{\circ} \mathrm{C}\right)$, and at the peak of the oil window is in the range of 0.65 to $0.9\left(T_{\max }=445\right.$ to $\left.450{ }^{\circ} \mathrm{C}\right)$ (Tissot and Welteh 1978; Peters and Cassa 1994). Based on the plot of $T_{\max }$ versus Ro\% (Fig. 14b), the Kazhdumi Formation is considered as a mature source rock and falls in the oil window zone. Conversely, the Pabdeh Formation situated out of this zone and considered as an immature source rock. Also, it is interesting to note that for the Kazhdumi Formation in well number 55, mean reflectance value of the one sample at a depth of $3182 \mathrm{~m}$ is $0.52 \%$, while another sample in well number 83 at a lower depth $(3040 \mathrm{~m})$ has higher mean reflectance value (0.68\%) (Fig. 15). This condition can stem from some factors, including measurement error, misidentification, caving, suppression, change in geothermal gradient and faulting (Dembicki 2016). However, figuring out the cause of different values of mean vitrinite reflectance for the Kazhdumi Formation in studied two wells requires more investigation using geological data.

Moreover, carbon preference index (CPI) proposed by (Bray and Evans 1961) is utilized as a thermal maturity index. High values of CPI $(>1)$ are indicative of low thermal maturity, while CPI values almost 1 in source rock extracts and crude oils represent a high level of the thermal maturity (El Diasty et al. 2016; Peters et al. 2005). CPI values for the Kazhdumi Formation (0.99 in well number 55 and 1.02 in well number 83) indicate high thermal maturity, while high values for the Pabdeh Formation (1.35 in well number 55 and 1.53 in well number 83) suggest low thermal maturity. Also, in this research, steranes and hopanes, which are important maturity-related biomarkers (Peters and Moldowan 1993), were applied to evaluate the thermal maturity of samples. Isomerization at C-20 in the C29 $5 \alpha, 14 \alpha$, $17 \alpha(\mathrm{H})$-steranes causes $20 \mathrm{~S} /(20 \mathrm{~S}+20 \mathrm{R})$ to rise from 0 to approximately 0.5 (equilibrium $=0.52-0.55$ ) with increasing maturity (Seifert and Moldowan 1986). Furthermore, the $\mathrm{C}_{32} 17 \alpha(\mathrm{H}), 21 \beta(\mathrm{H}) 22 \mathrm{~S} / 22 \mathrm{~S}+22 \mathrm{R}$ homohopane ratio has been implemented widely as a biomarker sign of thermal maturity (Moldowan et al. 1990). During maturation, this ratio rises from 0 to roughly 0.6 (equilibrium $=0.57-0.62$ ) (Peters et al. 2005). According to the plot of $\mathrm{C}_{29}$ sterane $\beta \beta /$ $\beta \beta+\alpha \alpha$ versus $C_{29}$ sterane $20 \mathrm{~S} / 20 \mathrm{~S}+20 \mathrm{R}$ (Fig. 16a), and $\mathrm{C}_{32}$ hopane $22 \mathrm{~S} / 22 \mathrm{~S}+22 \mathrm{R}$ against $\mathrm{C}_{29}$ sterane $\beta \beta / \beta \beta+\alpha \alpha$ (Fig. 16b), the Kazhdumi Formation falls in the peak mature zone. In stark contrast, however, the Pabdeh Formation falls
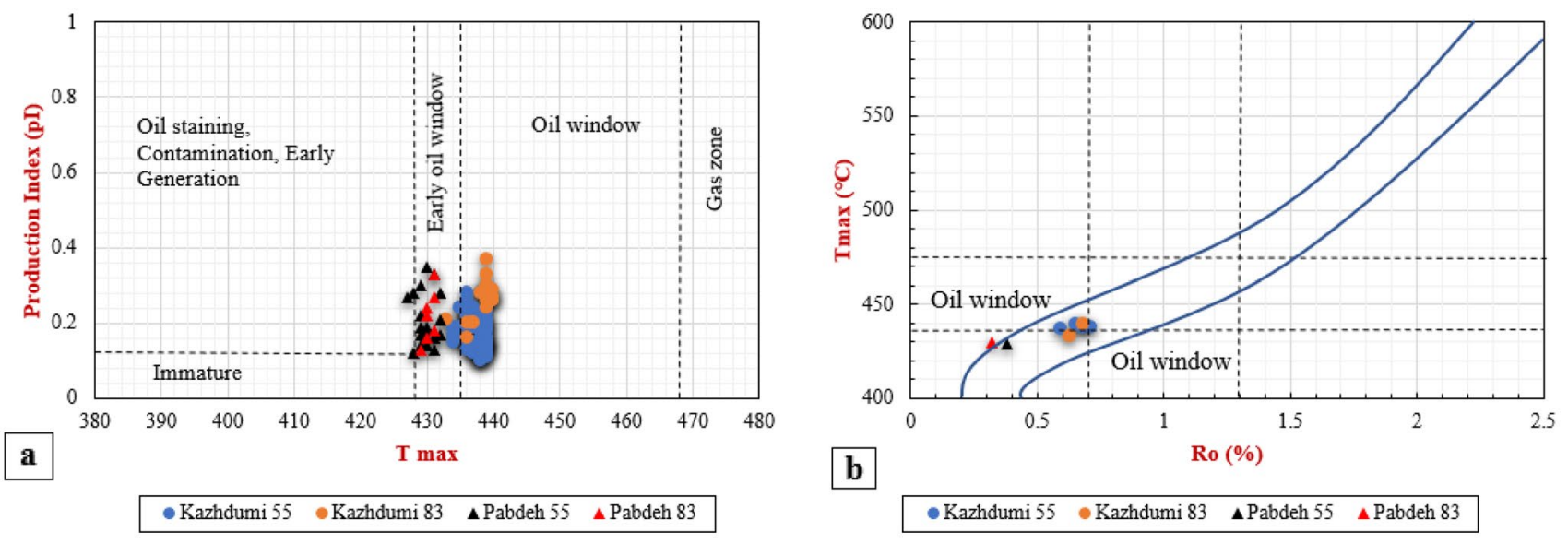

Fig. 14 a Plot of $T_{\max }$ against production index (PI) (modified after Al-Ameri and Zumberge 2012), and b vitrinite reflectance (Ro \%) against $T_{\max }$ (modified after Espitalie et al. 1985) 
Fig. 15 Cross-plot of mean vitrinite reflectance values versus depth for the Kazhdumi Formation
Well 55

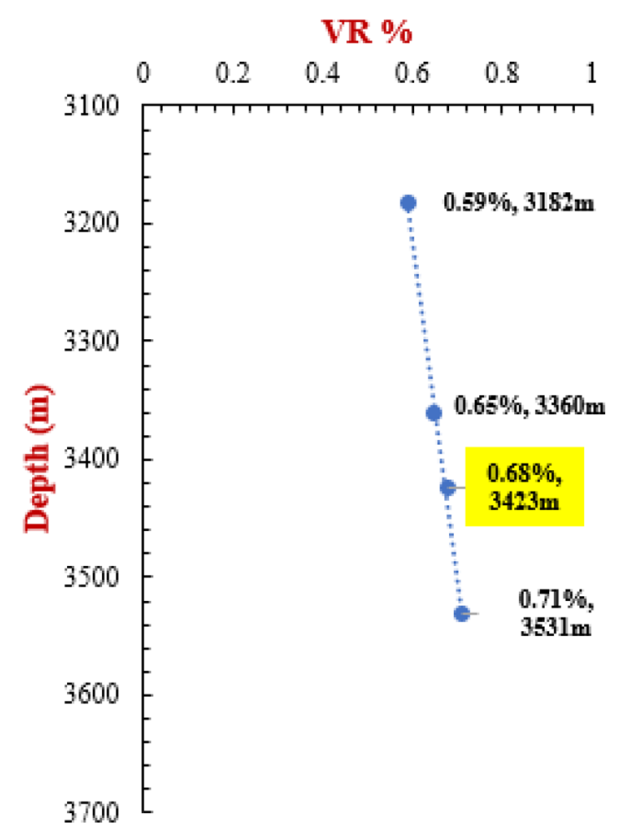

Well 83

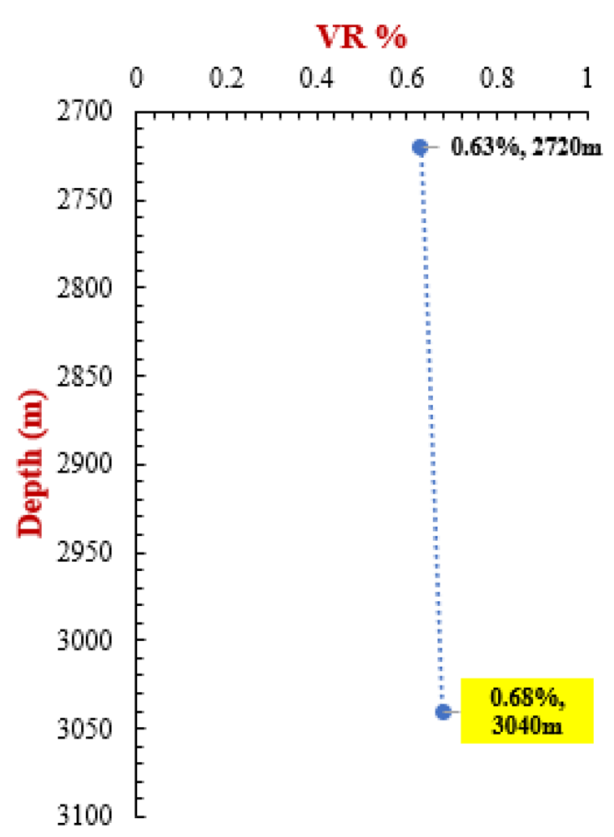

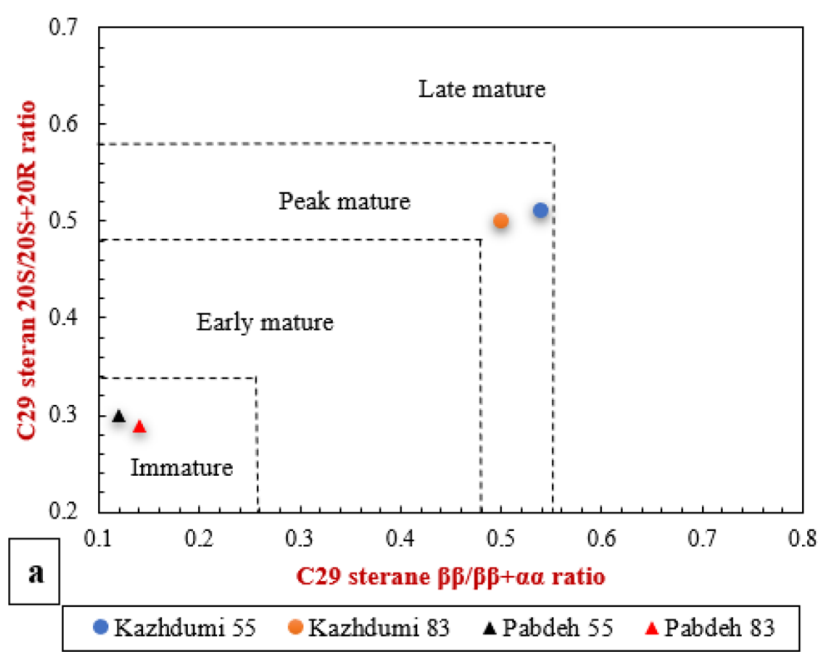

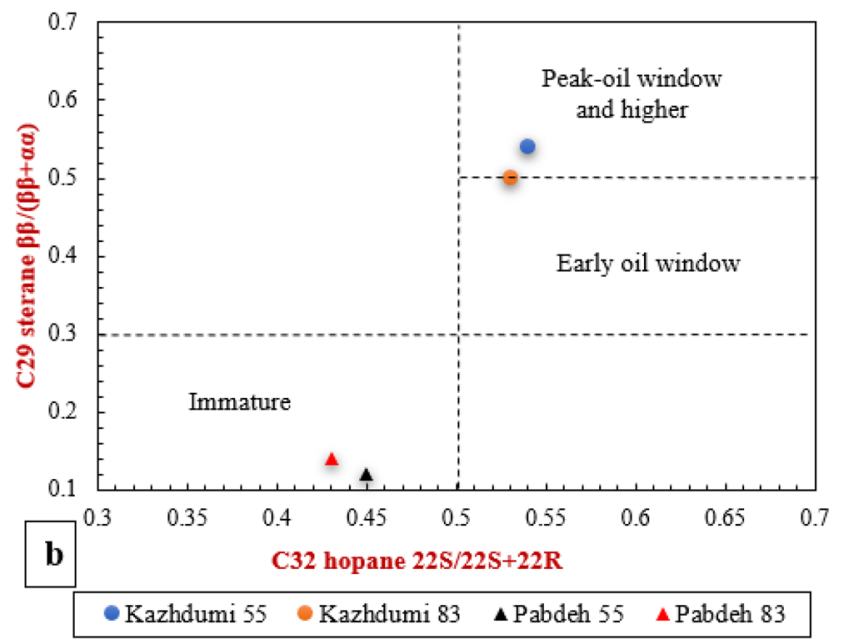

Fig. 16 a Cross-plot of $\mathrm{C}_{29}$ sterane $\beta \beta / \beta \beta+\alpha \alpha$ versus $\mathrm{C}_{29}$ sterane $20 \mathrm{~S} / 20 \mathrm{~S}+20 \mathrm{R}$ and $\mathbf{b} \mathrm{C}_{32}$ hopane $22 \mathrm{~S} / 22 \mathrm{~S}+22 \mathrm{R}$ against $\mathrm{C}_{29}$ sterane $\beta \beta / \beta \beta+\alpha \alpha$ to determine thermal maturity of rock samples (modified after Peters et al. 2005)

in the immature zone which confirms the low level of thermal maturity deducted from $\mathrm{T}_{\max }$ and obtained mean vitrinite reflectance values.

\section{Conclusion}

In conclusion, geochemical investigation of the Kazhdumi Formation as a possible source rock in Gachsaran Oilfield indicates that this formation with a "fair" to "good" capability of hydrocarbon generation predominately contains type II-III kerogen. The geochemical data/results/outcome shows that there is a close correlation between different parameters and the relationship between the petroleum potential and redox variation, especially in well number 55 . According to this $\log$, with increasing the anoxic condition, the petroleum potential would be increased for the Kazhdumi Formation.

However, facies and depositional environment-related biomarkers, including steranes and hopanes, suggest differences in lithology and depositional environment of the Kazhdumi Formation in well numbers 55 and 83. The Kazhdumi Formation in well number 55 has a shaly facies and deposited in a marine setting under oxic conditions, whereas 
this formation in well number 83 has carbonate lithology and deposited in a marine setting. In general, from data accomplished through instruments, it can be concluded that the Kazhdumi Formation in well number 83 had a better condition for the preservation of the organic matter and hence has more petroleum potential. Based on $\mathrm{T}_{\max }$, production index (PI), Ro\%, CPI as well as $\mathrm{C}_{29}$ steranes and $\mathrm{C}_{32}$ hopanes values, the Kazhdumi Formation is mature and falls in the oil window.

Geochemical assessment of the Pabdeh Formation suggests that this formation has a "poor" to "good" petroleum potential and contains a variety of kerogen types, including type II, type II-III, type III and even for one sample type IV, indicating deposition of this formation under different depositional conditions. A poor correlation between TOC and other Rock-Eval-derived petroleum potential indicators for the Pabdeh Formation at a depth of more than $2100 \mathrm{~m}$ may demonstrate the inert organic matter and mineral matrix effects at this depth interval. Moreover, biomarkers suggest that the Pabdeh Formation has a mixed or marly lithology (carbonate-shale) deposited in a marine setting under a suboxic-anoxic condition. Maturity-sensitive parameters such as $T_{\max }$, Ro\%, and maturity-distinctive biomarkers show that this formation is immature.

\section{Declaration}

Conflict of interests The authors declare that they have no known competing financial interests or personal relationships that could have appeared to influence the work reported in this paper.

Open Access This article is licensed under a Creative Commons Attribution 4.0 International License, which permits use, sharing, adaptation, distribution and reproduction in any medium or format, as long as you give appropriate credit to the original author(s) and the source, provide a link to the Creative Commons licence, and indicate if changes were made. The images or other third party material in this article are included in the article's Creative Commons licence, unless indicated otherwise in a credit line to the material. If material is not included in the article's Creative Commons licence and your intended use is not permitted by statutory regulation or exceeds the permitted use, you will need to obtain permission directly from the copyright holder. To view a copy of this licence, visit http://creativecommons.org/licenses/by/4.0/.

\section{References}

Al-Ameri TK, Zumberge J (2012) Middle and upper Jurassic hydrocarbon potential of the Zagross fold Belt, North Iraq. Mar Pet Geol 36:13-34

Al-Husseini M (2007) Iran's crude oil reserves and production. GeoArabia 12:69-94

Alizadeh B, Sarafdokht H, Rajabi M et al (2012) Organic geochemistry and petrography of Kazhdumi (Albian-Cenomanian) and Pabdeh (Paleogene) potential source rocks in southern part of the Dezful Embayment. Iran Org Geochem 49:36-46 ((In Persian))
Alsharhan AS, Kendall CGSC (1991) Cretaceous chronostratigraphy, unconformities and eustatic sealevel changes in the sediments of Abu Dhabi, United Arab Emirates. Cretac Res 12:379-401

Baban DH, Ahmed SM (2014) Vitrinite reflectance as a tool for determining level of thermal maturity for the Upper Jurassic Naokelekan and Barsarin Formations in Sargelu location, Kurdistan Region, NE Iraq. Arab J Geosci 7:2269-2277

Bordenave M (2002) The Middle Cretaceous to Early Miocene petroleum system in the Zagros domain of Iran, and its prospect evaluation. AAPG Annu Meet Am Assoc Pet Geol Houst 6:1-9

Bordenave M, Hegre J (2005) The influence of tectonics on the entrapment of oil in the Dezful embayment, Zagros foldbelt. Iran J Pet Geol 24:339-368

Bordenave ML, Hegre JA (2010) Current distribution of oil and gas fields in the Zagros Fold Belt of Iran and contiguous offshore as the result of the petroleum systems. Geol Soc London, Spec Publ 330:291-353

Bordenave ML, Huc AY (1995) The Cretaceous source rocks in the Zagros foothills of Iran. Rev L'institut Français Du Pet 50:727-752

Bray EE, Evans ED (1961) Distribution of n-paraffins as a clue to recognition of source beds. Geochim Cosmochim Acta 22:2-15

Carvajal-Ortiz H, Gentzis T (2015) Critical considerations when assessing hydrocarbon plays using Rock-Eval pyrolysis and organic petrology data: data quality revisited. Int J Coal Geol 152:113-122

Collister J, Ehrlich R, Mango F, Johnson G (2004) Modification of the petroleum system concept: Origins of alkanes and isoprenoids in crude oils. Am Assoc Pet Geol Bull 88:587-611

Daly AR, Edman JD (1987) Loss of organic carbon from source rocks during thermal maturation

Dembicki H (2016) Practical petroleum geochemistry for exploration and production. Elsevier

Dow W (1977) Kerogen studies and geological interpretations. J Geochemical Explor 7:79-99

El Diasty WS (2015) Khatatba Formation as an active source rock for hydrocarbons in the northeast Abu Gharadig Basin, north Western Desert. Egypt Arab J Geosci 8:1903-1920

Espitalié J (1986) Use of Tmax as a maturation index for different types of organic matter. Comparison with vitrinite reflectance. Therm Model Sediment basins 44:475-496

El Diasty WS, El Beialy SY, Mahdi AQ, Peters KE (2016) Geochemical characterization of source rocks and oils from northern Iraq: Insights from biomarker and stable carbon isotope investigations. Mar Pet Geol 77:1140-1162

Espitalie J, Deroo G, Marquis F (1985) La pyrolyse Rock-Eval et ses applications. Deuxième partie. Rev L'institut Français Du Pétrole 40:755-784

Hanson AD, Zhang SC, Moldowan JM et al (2000) Molecular organic geochemistry of the Tarim Basin, northwest China. Am Assoc Pet Geol Bull 84:1109-1128

Hao F, Zhou X, Zhu Y, Yang Y (2012) Lacustrine source rock deposition in response to co-evolution of environments and organisms controlled by tectonic subsidence and climate, Bohai Bay Basin, China. Org Geochem 42:323-339

Hosseiny E, Rabbani AR, Moallemi SA (2016) Source rock characterization of the Cretaceous Sarvak Formation in the eastern part of the Iranian sector of Persian Gulf. Org Geochem 99:53-66

Huang W-Y, Meinschein WG (1979) Sterols as ecological indicators. Geochim Cosmochim Acta 43:739-745

Hughes WB, Holba AG, Dzou LIP (1995) The ratios of dibenzothiophene to phenanthrene and pristane to phytane as indicators of depositional environment and lithology of petroleum source rocks. Geochim Cosmochim Acta 59:3581-3598

Hunt JM (1996) Petroleum geochemistry and geology. WH Freeman, New York 
Kamali M, Fathi Mobarakabad A, Mohsenian E (2006) Petroleum geochemistry and thermal modeling of Pabdeh Formation in Dezful Embayment. J Sci (university Tehran) 32:1-11

Lerch B, Karlsen DA, Matapour Z et al (2016) Organic geochemistry of Barents Sea petroleum: thermal maturity and alteration and mixing processes in oils and condensates. J Pet Geol 39:125-148

Li D, Li R, Wang B et al (2016) Study on oil-source correlation by analyzing organic geochemistry characteristics: a case study of the Upper Triassic Yanchang Formation in the south of Ordos Basin. China Acta Geochim 35(4):408-420

Maravelis AG, Chamilaki E, Pasadakis N et al (2017) Hydrocarbon generation potential of a Lower Permian sedimentary succession (Mount Agony Formation): Southern Sydney Basin, New South Wales, Southeast Australia. Int J Coal Geol 183:52-64

Mello MR, Telnaes N, Gaglianone PC, et al (1988) Organic geochemical characterisation of depositional palaeoenvironments of source rocks and oils in Brazilian marginal basins. In: Organic Geochemistry In Petroleum Exploration. Elsevier, pp 31-45

Moldowan JM, Sundararaman P, Schoell M (1986) Sensitivity of biomarker properties to depositional environment and/or source input in the Lower Toarcian of SW-Germany. Org Geochem 10:915-926

Moldowan JM, Fago FJ, Lee CY et al (1990) Sedimentary 12-n-propylcholestanes, molecular fossils diagnostic of marine algae. Sci 247:309-312

Neumeister S, Algeo T., Bechtel A, et al (2016) Redox conditions and depositional environment of the Lower Jurassic Bächental bituminous marls (Tyrol, Austria). Austrian J Earth Sci 109(2)

Peters KE (1986) Guidelines for evaluating petroleum source rock using programmed pyrolysis. Am Assoc Pet Geol Bull 70:318-329

Peters KE, Cassa MR (1994) Applied source rock geochemistry: Chapter 5: Part II. Essential elements

Peters KE, Moldowan JM (1993) The biomarker guide: interpreting molecular fossils in petroleum and ancient sediments

Peters KE, Walters CC, and Moldowan J. (2005) The Biomarker Guide: Biomarkers and isotopes in petroleum systems and Earth historye

Philp RP (1985) Biological markers in fossil fuel production. Mass Spectrom Rev 4:1-54

Sachsenhofer R, Shymanovskyy V, Bechtel A et al (2010) Palaeozoic source rocks in the Dnieprâ-"Donets Basin. Ukraine Pet Geosci 16(4):377-399

Safaei Farouji M, Rahimpour-Bonab H, Kamali M, Ghorbani B (2021) Oil-source rock correlation in super-giant Gachsaran oilfield. J Geosci 30:71-80

Safaei-Farouji M, Kamali M, Rahimpour-Bonab H et al (2021) Organic geochemistry, oil-source rock, and oil-oil correlation study in a major oilfield in the Middle East. J Pet Sci Eng 207:109074

Sarı A, Koca D, D€oner Z, Aliyev SA (2012) Nature of organic matter, thermal maturation and hydrocarbon potential of the Çamalan Formation in Central Anatolian Basin, Nallıhan/Ankara, Turkey. Strat Sedimentol Oil-Gas Basins 2:10-23
Seifert W, Moldowan J (1986) Use of biological markers in petroleum exploration. In: Johns RB (ed) Methods in geochemistry and Geophysics. Elsevier, Amsterda, pp 261-290

Sfidari E, Zamanzadeh SM, Dashti A et al (2016) Comprehensive source rock evaluation of the Kazhdumi Formation, in the Iranian Zagros Foldbelt and adjacent offshore. Mar Pet Geol 71:26-40

Shekarifard A, Daryabandeh M, Rashidi M et al (2019) Petroleum geochemical properties of the oil shales from the Early Cretaceous Garau Formation, Qalikuh locality, Zagros Mountains. Iran Int J Coal Geol 206:1-18

Sherkati S, Letouzey J (2004) Variation of structural style and basin evolution in the central Zagros (Izeh zone and Dezful Embayment). Iran Mar Pet Geol 21:535-554

Taylor GH, Teichmüller M, Davis A, et al (1998) organic petrology

Ten Haven HL, De Leeuw JW, Damsté JSS et al (1988) Application of biological markers in the recognition of palaeohypersaline environments. Geol Soc London, Spec Publ 40:123-130

Tissot BP, Welte DH (1984) Petroleum Formation and Occurrence

Tissot BP, Welte DH (1978) Petroleum formation and occurrence: a new approach to oil and gas exploration. Springer-Verlag, New York, p 538

Tissot B, Durand B, Espitalie J, Combaz A (1974) Influence of the nature and diagenesis of organic matter in the formation of petroleum. Am Assoc Pet Geol Bull 58:499-506

Volkman JK (1986) A review of sterol markers for marine and terrigenous organic matter. Org Geochem 9:83-99

Waples D (1985) Geochemistry in petroleum exploration. Springer, Dordrecht

Waples DW (1991) Biomarkers for geologists-a practical guide to the application of steranes and triterpanes in petroleum geology. Chap 2:5-10

Yandoka BMS, Abdullah WH, Abubakar MB et al (2016) Organic geochemical characterisation of shallow marine Cretaceous formations from Yola Sub-basin, Northern Benue Trough, NE Nigeria. J African Earth Sci 117:235-251

Zhang M, Li Z (2018) Thermal maturity of the Permian Lucaogou Formation organic-rich shale at the northern foot of Bogda Mountains, Junggar Basin (NW China): Effective assessments from organic geochemistry. Fuel 211:278-290

Zumberge JE (1984) Source rocks of the La Luna Formation (Upper Cretaceous) in the Middle Magdalena Valley, Colombia

Publisher's Note Springer Nature remains neutral with regard to jurisdictional claims in published maps and institutional affiliations. 